\title{
O FAROL, O OBSERVADOR E A VOZ: O DEBATE SOBRE A FEDERAÇÃO E A REFORMA CONSTITUCIONAL NA IMPRENSA PAULISTA (1830-1832)
}

\author{
Carlos Eduardo França de Oliveira ${ }^{1 ; 2}$
}

\section{Resumo}

Ancorado em estudos que apontam para a importância do elemento provincial na construção do Império brasileiro e o papel da imprensa periódica nesse processo, o presente artigo tem como objetivo analisar um aspecto específico da imprensa paulista durante o final do Primeiro Reinado e o início do período regencial, qual seja, o debate travado pelos jornais de São Paulo a respeito da federação e da reforma constitucional. A ideia central é questionar uma suposta homogeneidade presente no pensamento político paulista que não teria abrigado outros posicionamentos além de um liberalismo moderado consensual e hegemônico, ponto de vista que foi forjado pelos próprios agentes históricos da época e que ainda persiste em parte da historiografia sobre São Paulo nos Oitocentos. Busca-se, assim, problematizar o pensamento liberal paulista e indicar seus matizes, avanços e recuos, mostrando como o embate moderados versus exaltados revela não uma dicotomia inflexível, mas sim fissuras dentro do ideário liberal que transcendiam os limites da província e se articulavam à discussão política que envolvia o centro do Império e suas partes.

\section{Palavras-chave}

Imprensa periódica - Império - São Paulo.

\section{THE FAROL, THE OBSERVADOR AND THE VOICE: THE DISCUSS ABOUT FEDERALISM AND CONSTITUTIONAL REFORM IN SÃO PAULO PROVINCE PRESS (1830-1832)}

\section{Abstract}

Based on studies that trace the importance of the provincial element in the construction of the Brazilian Empire and the role of the periodic press in this process, this article aims to analyze a specific aspect of the Sao Paulo press during the end of Primeiro Reinado and the beginning of the Regency era, that is, the debate threaded by São Paulo newspapers regarding federation and constitutional reform. The central idea is to cast doubt on a supposed homogeneity present in São Paulo province political thought, which would not have harbored other positions beyond a moderated consensus and hegemonic liberalism, a point of view that was forged by the historical agents of the time and still persists in part of the historiography about São Paulo in the eighteenth century. It seeks to question the liberal thinking in São Paulo and indicate its nuances, advances and retreats, showing how the moderate versus exalted confrontation reveals not an inflexible dichotomy but rather cracks within the liberal ideology that transcended the boundaries of the province and were articulated to the political discussion that involved the center of the Empire and its parts.

\section{Keywords}

Press - Brazilian Empire - São Paulo.

${ }^{1}$ Universidade de São Paulo - São Paulo - São Paulo - Brasil.

2 Doutor em História Social pela Universidade de São Paulo. E-mail: carlosoliveira@usp.br 


\section{Introdução}

Há em curso uma vigorosa renovação historiográfica no âmbito dos estudos sobre o Brasil nos Oitocentos. Trabalhos desenvolvidos nas últimas décadas dentro das universidades brasileiras vêm apontando para uma releitura da história política do Império, ao abordar questões como a formação da opinião pública, a constituição de projetos políticos, a atuação de estadistas e matizados segmentos sociais e os nexos da sociedade imperial com a escravidão. Tais estudos têm repensado a preeminência do econômico sobre a prática política e a cisão entre ideias e realizações sociais, rompendo assim com o paradigma explicativo da polarização entre dominantes e dominados e lançando luz, por conseguinte, ao caráter fundamental da cultura e da iniciativa dos homens na construção das sociedades modernas ${ }^{3}$.

Embora ancoradas em matrizes teórico-metodológicas distintas, teses e dissertações têm posto em xeque uma das interpretações mais persistentes sobre a formação do Estado brasileiro: a de que sua gênese se deu em meio a uma contradição incontornável, expressa na incongruência entre os princípios liberais e a realidade brasileira, supostamente timbrada pelo legado colonial, pela escravidão e pela ausência de projetos que vislumbrassem transformações sociais efetivas por parte daqueles que conduziram o processo de construção do novo Estado-nação. Em contrapartida, essas novas pesquisas vêm questionando a premissa do atraso da sociedade brasileira oitocentista em relação à modernidade europeia e estadunidense, bem como a ideia do inacabamento da nação e da incapacidade de se erigir entre os brasileiros uma monarquia constitucional representativa que contemplasse os interesses, ainda que divergentes, dos agentes políticos em disputa ${ }^{4}$.

Tal esforço coletivo tem revisitado períodos específicos como o das regências que aos poucos vem se livrando do estigma de ser um tempo caótico, meramente transitório, espécie de entreato menor situado entre o primeiro e o segundo reinados. Cada vez mais os anos 1830 são considerados decisivos para a consolidação das bases do Estado imperial, seja no que tange ao aparato jurídico-administrativo, seja no delineamento dos grupos políticos que tomaram a dianteira da máquina pública ${ }^{5}$. A ideia de um "grande laboratório de formulações e práticas políticas e sociais", obviamente calcado na luta política, tem ganhado eco e se sobreposto às corriqueiras concepções de desordem e turbulência.

Um elemento de aproximação entre trabalhos atuais sobre o período regencial é o emprego da imprensa periódica como fonte privilegiada de análise. Utilizados tradicionalmente como elemento comprobatório ou elucidativo de um discurso historiográfico previamente concebido, os periódicos passaram a receber uma atenção especial, sobretudo a partir da década de 1970, por parte de historiadores preocupados em compreender a política do Império por um viés que não aquele alinhado exclusivamente às esferas oficiais de poder. De lá pra cá a imprensa tem figurado como instrumento de discussão política, na medida em que, além de ressoar concepções e propostas voltadas para o tema da instauração do governo constitucional e dos instrumentos da cidadania, desempenhou papel fundamental enquanto aparelho doutrinador do posicionamento político da época ${ }^{7}$. Se, por um lado, a análise de um impresso permite diagnosticar o perfil ideológico daqueles elementos que o sustentam,

\footnotetext{
${ }^{3}$ MARSON, Izabel Andrade; OLIVEIRA, Cecilia Helena de Salles. Liberalismo, monarquia e negócios: laços de origem. In: MARSON, Izabel Andrade; OLIVEIRA, Cecilia Helena de Salles (org.). Monarquia, liberalismo e negócios no Brasil: 1780-1860. São Paulo: Edusp, 2013. p. 9-33.

${ }^{4}$ CARVALHO, José Murilo de (org.). Nação e cidadania no Império: novos horizontes. Rio de Janeiro: Civilização Brasileira, 2007; GRINBERG, Keila; SALLES, Ricardo (org.). O Brasil imperial. Rio de Janeiro: Civilização Brasileira, 2009; OLIVEIRA, Cecilia Helena L. de Salles; BITTENCOURT, Vera Lúcia N.; COSTA, Wilma Peres (org.). Soberania e conflito: configurações do estado nacional no Brasil do século XIX. São Paulo: Hucitec, 2010; PEIXOTO, Antônio Carlos; GUIMARÃES, Lucia Maria Paschoal; PRADO, Maria Emília (org.). O liberalismo no Brasil imperial: origens, conceitos e prática. Rio de Janeiro: Editora Revan, 2001; RIBEIRO, Gladys (org.). Brasileiros e cidadãos: modernidade política, 1822-1930. São Paulo: Alameda, 2009.

${ }^{5}$ BASILE, Marcello. O Império em construção: projetos de Brasil e ação política na Corte regencial. Tese (Doutorado em História), Universidade Federal do Rio de Janeiro, Rio de Janeiro, 2004; Idem. O laboratório da nação: a era regencial (1831-1840). In: GRINBERG, Keila; SALLES, Ricardo (org.). O Brasil imperial. Rio de Janeiro: Civilização Brasileira, 2009. p. 53-120; MOREL, Marco. As transformações dos espaços públicos: imprensa, atores políticos e sociabilidade na cidade imperial (1820-1840). São Paulo: Hucitec, 2005; SLEMIAN, Andréa. Sob o império das leis: constituição e unidade nacional na formação do Brasil (1822-1834). Tese (Doutorado em História), Faculdade de Filosofia, Letras e Ciências Humanas, Universidade de São Paulo, 2006.

${ }^{6}$ MOREL, Marco. O período das regências (1831-1840). Rio de Janeiro: Jorge Zahar Editora, 2003. p. 09.

7 FERREIRA, Tania Maria Bessonde da C.; MOREL, Marco; NEVES, Lucia Maria Bastos Pereira (org.). História e imprensa: representações culturais e práticas de poder. Rio de Janeiro: DP\&A/ Faperj, 2006; MARTINS, Ana Luiza; LUCA, Tania Regina de (org.). História da imprensa no Brasil. São Paulo: Editora Contexto, 2008.
} 
por outro, evidencia a forma retórico-pedagógica com que tais grupos se valeram para enunciar seus pressupostos e formas de ação sobre a organização do Império. Assim, mais do que um veículo de disseminação de ideias, a imprensa tinha como objetivo formá-las e combatê-las e, ao mesmo tempo, servir como estratégia de projeção, uma vez que grande parte dos redatores e colaboradores representava grupos políticos e econômicos e visava intervir nos pleitos eleitorais. Como nos lembra Marco Morel, foi somente em um contexto de modernização das esferas política e cultural, dentro do qual se moldou um espaço público alicerçado em opiniões distintas, que a imprensa conseguiu desempenhar essa característica polivalente ${ }^{8}$.

No que tange às regências, além de estabelecer um contraponto às fontes comumente utilizadas - em sua maioria de caráter oficial, como os Anais do Parlamento -, a análise dos jornais estimula o historiador a recompor o calor dos debates da época, com suas idas e vindas, procedimento que auxilia a descortinar grupos e personagens que foram turvados ou encerrados em categorias estanques pelas narrativas tradicionais, enfoque que ganha relevo quando nos lembramos da especificidade do político e da importância dos agentes sociais na elaboração de conceitos e projetos de Estado9 ${ }^{9}$ A aproximação entre debate e ação política promovida pela imprensa expõe como temas e problemas foram arquitetados e reelaborados ao sabor das circunstâncias, mas sempre em sintonia com projetos de maior amplitude.

Os jornais têm encorajado, também, aqueles historiadores empenhados em esmiuçar o papel da dimensão local, sobretudo das províncias, na viabilização de um estado monárquico-constitucional com sede no Rio de Janeiro. À contracorrente de interpretações mais difundidas que tendem a compreender o nascimento do Império como o desfecho de um conjunto de acordos políticos de caráter clientelista, autores vêm matizando o entendimento a respeito da estrutura política imperial a partir da ênfase no estudo da dimensão provincial que, no limite, consistiu na principal esfera de poder local durante os primeiros anos do Império. Esse destaque conferido às instâncias locais tem ampliado o conhecimento referente às diferentes províncias, possibilitando construir um painel mais completo de suas diferenças, semelhanças e peculiaridades, o que sugere olhar a construção da monarquia brasileira por um ângulo diferente: a consolidação do Estado imperial no decurso do século XIX não seria o produto de uma mera cooptação dos elementos provinciais pelo governo central enraizado no Rio de Janeiro, dominador e consensualmente estabelecido. Ela seria, antes, o resultado de um complexo jogo político em que os agentes provinciais pugnaram - por exemplo, por meio da imprensa - no sentido de consolidarem sua participação no controle do novo Estado a ser construído ${ }^{10}$.

Considerando a importância do elemento provincial na configuração do nascente Estado nacional brasileiro e o papel da imprensa periódica nesse contexto, o presente artigo tem como objetivo examinar um aspecto específico da imprensa paulista durante o término do Primeiro Reinado e o início do período regencial, qual seja, o debate travado pelos jornais de São Paulo a respeito da federação e da reforma constitucional. Intenta-se questionar uma pretensa coesão no ideário político paulista que não teria visto florescer outras linhas de pensamento além de um liberalismo moderado hegemônico, como ainda insiste parcela da historiografia sobre São Paulo no século XIX. Ao destrinchar o pensamento liberal paulista entre fins da década de 1820 e início da seguinte, torna-se possível observar como a defrontação entre moderados e exaltados desmonta a ideia de uma dicotomia rígida, revelando, em vez disso, fissuras internas ao pensamento liberal que ultrapassavam os limites da província e que se articulavam ao panorama político que enredava o núcleo do Império e suas partes. Para tanto serão utilizados, especialmente, os jornais O Farol Paulistano, O Observador Constitucional e A Voz Paulistana.

Cumpre ressaltar que estudar a imprensa paulista desse período é encarar, necessariamente, uma

\footnotetext{
${ }^{8}$ MOREL, Marco. As transformações dos espaços públicos... Op. Cit.

${ }^{9}$ ROSANVALLON. Pierre. Por uma história do político. São Paulo: Alameda Casa Editorial, 2010.

${ }^{10}$ CARVALHO, Marcio Eurélio Rios de. Afirmação de uma esfera pública de poder em Minas Gerais (1821-1851). Tese (Doutorado em História), Universidade Federal de Minas Gerais, 2003; DOLHNIKOFF, Miriam. O pacto imperial: origens do federalismo no Brasil. São Paulo: Globo, 2005; GOUVÊA, Maria de Fátima Silva. O Império das províncias. Rio de Janeiro, 1822-1889. Rio de Janeiro: Civilização Brasileira/Faperj, 2008; SILVA, Wlamir. "Liberais e povo": a construção da hegemonia liberal-moderada na província de Minas Gerais (1830-1834). São Paulo: Hucitec, 2009.
} 
carência de fontes que inviabiliza pesquisas mais abrangentes sobre o tema ${ }^{11}$. Num comparativo com Minas Gerais e Rio de Janeiro, por exemplo, São Paulo viu nascer poucos periódicos - alguns de brevíssima duração - dos quais infelizmente restaram séries bastante incompletas. Há, portanto, uma questão metodológica que não pode ser desprezada, sobretudo no que diz respeito a generalizações sobre posicionamentos político-ideológicos dos jornais trabalhados. Diante disso a maioria dos estudos acaba adotando cronologias mais $\operatorname{curtas}^{12}$ ou, alternativamente, os periódicos se convertem num recurso documental auxiliar e não propriamente em objeto específico de pesquisa.

Por fim, mais uma ressalva. A imprensa paulista de fins do Primeiro Reinado e início das regências foi, antes de tudo, uma imprensa exclusivamente paulistana, ou seja, sediada na cidade de São Paulo, uma vez que apenas na década de 1840 despontaram jornais fora da capital ${ }^{13}$. Isso não significa, entretanto, que vozes de outras partes da província não se fizessem ouvir. São Paulo, porque capital, era por excelência o palco da política paulista, seja por abrigar as mais altas esferas do poder institucionalizado, seja por contar com um espaço extraoficial de debate mais dinâmico, que fazia confluir homens e ideias de outras partes da província.

\section{A província de São Paulo no início do século XIX}

Em princípios do século XIX, o adensamento do movimento de mercantilização da produção e da concentração fundiária no centro-sul, aliado às disputas pelo controle do mercado fluminense, do comércio de cabotagem e das atividades importadoras e exportadoras, impulsionou embates intensos entre negociantes radicados na Corte e no Reino de Portugal, mercadores ingleses, proprietários do sul de Minas, do norte fluminense (Recôncavo e Campos de Goitacases) e de São Paulo, áreas que viram florescer uma economia dinâmica, com possibilidades variadas de produção e mercado, que era atrativa para setores diversos da população ${ }^{14}$.

São Paulo tinha entre suas figuras de maior realce na política, entre as décadas de 1820 e 1830, homens que se atrelavam ao chamado "quadrilátero do açúcar", designação utilizada para dar nome à principal região produtora/exportadora de açúcar de São Paulo entre fins do século XVIII e primeira metade do século XIX, e que era delimitado pelas vilas de Sorocaba, Piracicaba, Mogi-Guaçu e Jundiaí, mas também incluía vilas como Itu e São Carlos ${ }^{15}$. Embora integrante do quadrilátero, a vila de Sorocaba notabilizava-se por outra atividade econômica relevante - o negócio do gado, importante dinamizador econômico e político da região centro-sul, posto que o comércio de reses e muares articulava os centros produtores (Rio Grande do Sul e os "Campos Gerais" de Curitiba) e vendedores (Sorocaba e a cidade de São Paulo) com os compradores (região planaltina paulista, Minas Gerais e, sobretudo, o Rio de Janeiro $)^{16}$. A província contava, ainda, com outras regiões produtoras, como os litorais sul (cereais) e norte (açúcar, aguardente), os vales do Ribeira (rizicultura) e do Paraíba (gêneros de subsistência, criação de animais, e início das lavouras de café) e o "sertão do rio Pardo" (gêneros de primeira necessidade e pecuárias leiteira), além de áreas de concentração comercial e escoamento, como a capital paulista (entroncamento viário e espaço privilegiado de negócios) e a vila de Santos, detentora do principal porto da província ${ }^{17}$.

\footnotetext{
${ }^{11} \mathrm{O}$ estudo mais abrangente sobre a imprensa paulista na primeira metade do século XIX ainda é o de Arnaldo Contier, publicado ao final da década de 1970. Cf. CONTIER, Arnaldo. Imprensa e ideologia em São Paulo, 1822-1842: matizes do vocabulário político e social. Petrópolis: Vozes, 1979. Ver também FREITAS, Afonso de. A imprensa periódica de São Paulo. Revista do Instituto Histórico e Geográfico de São Paulo, vol. 19, p. 322-1133, 1915.

${ }^{12}$ OLIVEIRA, Carlos Eduardo França de. Poder local e palavra impressa: São Paulo, 1824-1834. São Paulo: Annablume/Fapesp, 2011; HÖRNER, Erik. A tribuna em praça pública: debate político na imprensa periódica paulistana (1838-1842). In: OLIVEIRA, Cecilia L. de Salles; PRADO, Maria Lígia Coelho; JANOTTI, Maria de Lourdes Mônaco (org.). A história na política, a política na história. São Paulo: Alameda, 2006. p. 59-80.

${ }^{13}$ A imprensa demorou a se espalhar nas demais localidades da província, tal como em Sorocaba (1842), Santos (1841), Itu (1849), Guaratinguetá (1859), Campinas (1860), Taubaté (1861) e Pindamonhangaba (1863).

${ }^{14}$ OLIVEIRA, Cecilia Helena L. de Salles. A astúcia liberal. Relações de mercado e projetos políticos no Rio de Janeiro (1820-1824). São Paulo: Ícone e Edusf, 1999. p. 80.

${ }^{15}$ PETRONE, Maria Thereza Schorer. A lavoura canavieira em São Paulo. Expansão e declínio (1765-1851). São Paulo: Difusão Europeia do Livro, 1968.

${ }^{16}$ PETRONE, Maria Thereza Schorer. O barão de Iguape. Um empresário da época da Independência. São Paulo: Cia. Editora Nacional, 1976.

${ }^{17}$ LUNA, Francisco Vidal; KLEIN, Herbert S. Evolução da Sociedade e Economia Escravista de São Paulo, de 1750 a 1850. São Paulo: 
É conhecida a importância de São Paulo durante a Independência e os primeiros passos da construção do Império. Ao lado de Minas Gerais, São Paulo figura na historiografia tradicional como partícipe de um adesismo mais ou menos consensual em torno do projeto de poder encabeçado por d. Pedro. Esta tese é contestada por estudos que vêm apontando para uma solução negociada entre setores provinciais e o círculo do monarca, tendo como pano de fundo uma maior inserção nas redes de poder e negócios proporcionadas por um novo governo estruturado no Rio de Janeiro. A aproximação com a ideia da criação de um Estado independente passava, necessariamente, pela afirmação de um poder provincial, ainda que os termos de seu funcionamento estivessem por construir ${ }^{18}$.

Esse ponto é fundamental para entender como já na gênese do Estado nacional brasileiro houve uma divisão das forças políticas provinciais que se viram mais ou menos contempladas pela nova máquina pública. Se, de um lado, o comprometimento dos setores regionais com o Estado foi crucial para a sustentação da monarquia brasileira, ajudando a assegurar a integridade nacional e sua base institucional, de outro, permitiu aos mesmos grupos provinciais mecanismos para granjearam participação política na Corte. Muitos deles haviam aderido ao movimento vintista em 1821, período em que cultivaram a expectativa de que o constitucionalismo luso-brasileiro franqueasse o autogoverno e a ampliação dos poderes provinciais, bem como garantisse uma maior inclusão na praça fluminense. Quando o desenrolar dos acontecimentos tornou essa possibilidade pouco viável, parte desses homens se aliou momentaneamente a figuras como José Bonifácio e Nogueira da Gama e deram suporte ao Fico e ao governo de d. Pedro, na esperança de que futuramente poderiam ter suas aspirações atendidas. Porém, derrotados na Constituinte, viram seus interesses contemplados de forma limitada pela Carta de 1824 .

Nem todos aqueles que vivenciaram as negociações referentes à inclusão de São Paulo no projeto pedrino - ou pelo menos lhes emprestaram apoio - foram, portanto, beneficiados diretamente. Políticos como José da Costa Carvalho, Rafael Tobias de Aguiar, Nicolau Vergueiro, Paula Sousa e Diogo Feijó, embora apoiadores da Independência por meio das câmaras municipais, da magistratura e das milícias locais, não foram arregimentados para cargos decisórios na Corte, em grande medida porque ainda não detinham envergadura política necessária para fazer frente aos grandes produtores e comerciantes arraigados em torno do Rio de Janeiro desde meados do século XVIII. Recém-iniciado o Primeiro Reinado, todavia, esses personagens conquistaram cada vez mais espaço no cenário imperial, percorrendo um itinerário de duas mãos - da província para o centro do Império e vice-versa -, fazendo dessa articulação uma condição necessária para sua sobrevivência política.

Tal cenário tomou proporções ainda maiores com a abdicação. Paulistas que até ali se opuseram ao governo de d. Pedro tinham certeza de que o governo constitucional estava cimentado, ainda que houvesse divergências sobre o seu formato. Nesse sentido, mais do que acompanharem o afastamento do monarca, esses setores estavam preocupados em participar da construção do novo governo, tanto que o que se delineou a partir daí foi a edificação de uma das maiores bases de apoio da qual a Regência gozaria até o Ato Adicional, a despeito das divergências e contestações presentes em solo paulista. Em questão de pouco tempo, líderes da oposição parlamentar do Primeiro Reinado ocupariam cargos estratégicos na máquina pública, o que tornou ainda mais estreitos os vínculos entre São Paulo e Rio de Janeiro.

\section{A origem da imprensa paulista e o fortalecimento do discurso liberal-moderado}

Em que pese a importância de São Paulo no quadro acima esboçado, foi apenas com o surgimento de O Farol Paulistano em fevereiro de 1827 que a imprensa periódica se enraizou em terras paulistas, após algumas tentativas frustradas. A folha dirigida por José da Costa Carvalho ${ }^{19}$ permaneceria a

\footnotetext{
Edusp, 2006.

${ }^{18}$ BITTENCOURT, Vera Lúcia Nagib. De alteza real a imperador: o governo do príncipe d. Pedro, de abril de 1821 a outubro de 1822. Tese (Doutorado em História), Faculdade de Filosofia, Letras e Ciências Humanas, Universidade de São Paulo, São Paulo, 2007; DOLHNIKOFF, Miriam. São Paulo na Independência. In: JANCSÓ, István (org.). Independência: história e historiografia. São Paulo: Hucitec/Fapesp, 2005b. p. 557-575; NEVES, Lucia Maria Bastos Pereira das. São Paulo e a Independência. In: SILVA, Maria Beatriz Nizza da (org.). História de São Paulo colonial. São Paulo: Ed. Unesp, 2009. p. 275-318; OLIVEIRA, Cecilia Helena de Salles. São Paulo e a Independência. In: CAMARGO, Ana Maria de Almeida (org.). São Paulo, uma longa história. São Paulo: Centro de Integração Escola/Empresa, 2004. p. 39-58.

${ }^{19}$ José da Costa Carvalho (1796-1860), barão, visconde e depois marquês de Monte Alegre, era natural da freguesia da Nossa Senhora dossiê Regência e Imprensa
} 
única da província até o aparecimento, em outubro de 1829, de O Observador Constitucional, jornal comandado pelo médico italiano Líbero Badaró ${ }^{20}$. Costa Carvalho e Antônio Mariano de Azevedo Marques $^{21}$ cuidavam da redação de $O$ Farol Paulistano que também contava com contribuições esporádicas de nomes como Manoel Joaquim do Amaral Gurgel, Manoel Odorico Mendes, Vicente Pires da Mota e Nicolau Vergueiro. À frente da redação de O Observador estavam Líbero Badaró e Luiz Monteiro de Ornellas que provavelmente assumiu o jornal após o assassinato do médico italiano em novembro de 1830 .

O surgimento dos dois jornais não foi acidental. O revigoramento da imprensa periódica após a outorga da Carta de 1824 estava associado à abertura da primeira legislatura do Império, ocorrida em maio de 1826, e à consequente ampliação do debate político desenvolvido dentro e fora das esferas oficiais de poder, iniciando-se ali uma clivagem política para os representantes eleitos no início do Primeiro Reinado, que viram nesse ato uma vitória do constitucionalismo, num contexto em que a configuração política do Império apresentava-se insustentável. Afinal, o jovem imperador vinha mantendo uma monarquia constitucional cujas bases de representação parlamentar ainda não tinham sido instituídas. Sendo assim, a maior parte dos impressos surgidos nesse contexto professava os preceitos mais genéricos do liberalismo pós-Revolução Francesa e afinava-se com a oposição feita pela Câmara dos Deputados ao governo de d. Pedro e, em determinados pontos, ao Senado, de forma que parte de seus mantenedores/redatores era composta por membros da própria câmara baixa, como Evaristo da Veiga (Aurora Fluminense), Bernardo Pereira de Vasconcelos (O Universal) e José da Costa Carvalho (O Farol Paulistano). Alguns desses homens só tomariam assento na segunda legislatura (1830-1833), como foi o caso de Evaristo, fato que reitera a importância da imprensa como trampolim político.

Classificados pela bibliografia como liberais "moderados", terminologia utilizada pelos próprios coevos, os homens envolvidos na publicação desses periódicos bem como no estabelecimento da oposição parlamentar ao governo pedrino julgavam-se adeptos da "moderação", conceito que se apresentava, amiúde, mais como um instrumento analítico das diversas esferas da sociedade civil organizada do que uma posição política rigorosamente demarcada. Espécie de visão de mundo baseada no "justo equilíbrio" das coisas - uma releitura, dentre outras influências, da concepção de justmilieu empregada pelos liberais franceses das primeiras décadas do século XIX, que buscava fixar um ponto de equilíbrio entre a estrutura sociopolítica do Antigo Regime, o legado iluminista e a experiência revolucionária de 1789 -, a moderação brasileira emprestou concepções e vocabulários do debate político-conceitual ocorrido na península Ibérica no início do século XIX. Tanto a elaboração e execução da Constituição de Cádiz, na Espanha, quanto a eclosão do movimento revolucionário do Porto foram permeados pela discussão em torno de um liberalismo dito moderado que, em linhas gerais, deveria equacionar a soberania monárquica com os demais poderes assegurados pela Constituição ${ }^{22}$. No caso específico do Império brasileiro, tratava-se de criar um aparato jurídico-

da Penha, situada nos arredores de Salvador. Filho de pai homônimo e de Ignez Maria Piedade Costa, estudou Leis na Universidade de Coimbra, onde se formou em 1819. De volta ao Brasil, iniciou sua carreira pública pela magistratura, ocupando os cargos de juiz de fora e ouvidor da cidade de São Paulo, entre 1821 e 1822, período em que se casou com Genebra de Barros Leite, viúva do brigadeiro Luís Antônio de Sousa Queiróz. Sua carreira política iniciou-se quando foi eleito ao cargo de deputado pela Bahia para a Assembleia Constituinte de 1823. Ao longo do Primeiro Reinado, foi deputado pela Bahia nas duas primeiras legislaturas. Durante esse período, foi presidente da Câmara dos Deputados (de 5 de maio a 3 de julho de 1828; de 4 de maio a 3 de julho de 1830 ; de 3 de agosto de 1830 a 4 de maio de 1831); vice-presidente da Câmara dos Deputados (de 4 de maio de 1827 a 5 de maio de 1828); e primeiro suplente da Mesa Diretora (de 2 de agosto de 1828 a 4 de maio de 1829). Ainda durante o Primeiro Reinado, Costa Carvalho foi membro regular dos conselhos da Presidência e Geral de São Paulo. Com a abdicação, tornou-se membro da Regência Trina Permanente em 17 de junho de 1831.

${ }^{20}$ Giovanni Battista Líbero Badaró (?-1830) era natural da Itália, onde cursou medicina, mudando-se para o Rio de Janeiro em 1826. Badaró fixou-se na cidade de São Paulo em 1828, a convite de Costa Carvalho. Deste foi hóspede temporariamente, até sua mudança para um edifício na rua S. José, nas proximidades da tipografia. Além de médico e redator, Badaró ministrava aulas preparatórias de Geometria para o Curso Jurídico da cidade de São Paulo.

${ }^{21}$ Antônio Mariano de Azevedo Marques (1797-1844), o “mestrinho”, era natural de São Paulo. Filho de Manoel Eufrásio de Azevedo Marques, tornou-se conhecedor de latim já em sua juventude, fazendo com que desse aulas para os integrantes do coral da catedral da Sé, quando recebeu o apelido de mestrinho. Em 1822, foi nomeado professor da cadeira pública de Latim e Retórica da cidade de São Paulo. Em 1828, quando da fundação do Curso Jurídico de São Paulo, ocupou a cadeira de Latim e Retórica anexa ao Curso Jurídico, cargo que desempenhou até 1835. Entre as décadas de 1820 e 1830, ocupou os cargos de escrivão da irmandade de Santa Casa de Misericórdia (1823-1825), juiz de paz, vereador, membro dos conselhos da Presidência e Geral, vice-presidente (1837) e secretário da Presidência (1839-1842), todos pela província de São Paulo. No fim da vida, ainda ocupou o cargo de auxiliar de gabinete do visconde de Macaé no Rio de Janeiro.

${ }^{22}$ MOREL, Marco. As transformações dos espaços públicos... Op. Cit., p. 117-118. 
administrativo que ao mesmo tempo proporcionasse a divisão dos poderes, a criação de instituições representativas, a limitação da atuação dos governantes e a manutenção dos direitos dos cidadãos, sem pleitear, todavia, uma organização social que dilatasse o espaço de cidadania já assegurado pela Carta de $1824^{23}$.

Representantes desse liberalismo moderado ainda em gestação, tanto o Farol Paulistano quanto o Observador Constitucional eram impressos na Tipografia do Farol Paulistano, situada no centro da capital paulista, fato que provocou uma sequela importante: até pelo menos fins de 1830, houve um claro alinhamento editorial entre os dois jornais, que dispuseram do monopólio da palavra impressa na província até janeiro de 1831, com o surgimento de A Voz Paulistana. Tal proximidade traduziuse na busca constante por uma hegemonia discursiva que visava consolidar e naturalizar o discurso moderado, imputando à província um perfil político homogêneo, livre de contradições. Além disso, a ausência, até pouco antes da abdicação, de um jornal conterrâneo com posicionamento políticoideológico divergente, fez com que O Farol Paulistano e o Observador Constitucional entrassem em choque com folhas de fora da província, sobretudo de Minas Gerais e Rio de Janeiro, atitude que se tornou traço distintivo da imprensa paulista durante os anos seguintes, até porque apenas na década de 1840 surgiriam impressos fora da capital.

Até fins do ano de 1830, as duas publicações paulistas tencionaram firmar um lugar na esfera pública estruturada pela imprensa periódica do centro-sul do Império, por meio da demarcação de um cenário político conflituoso, no limite bipolar, entre "liberais"/"constitucionais" versus "absolutistas"/“corcundas”. Na prática, isso significou a publicação de artigos maniqueístas e de alto teor pedagógico, o alinhamento ou o afastamento em relação aos principais periódicos em circulação na Corte e em outras províncias, e a fixação de uma leitura própria sobre o andamento dos negócios públicos do Império, adotando-se critérios valorativos para a análise dos poderes Executivo (reacionarismo do Ministério versus constitucionalismo do monarca), Legislativo (apreciação da Câmara dos Deputados versus depreciação do Senado) e Judiciário (precariedade das formas antigas versus viabilidade das inovações propostas) $)^{24}$.

\section{Uma voz uníssona? \\ O contraponto exaltado na imprensa paulista e o início do debate sobre a federação e a reforma constitucional}

O discurso moderado predominante na imprensa paulista sofreu poucos sobressaltos até dezembro de 1830, quando os temas da federação, república e reforma constitucional granjearam espaço nas páginas de periódicos de todo o Império, em meio à maior visibilidade das propostas dos intitulados liberais "exaltados" ao final do Primeiro Reinado. Se, por um lado, é certo que os adversários políticos dos exaltados se valeram da indefinição do termo "federação" para associá-lo ao sistema republicano e, consequentemente, depreciá-lo ante aqueles que advogavam a favor da monarquia, por outro, os próprios defensores do sistema federativo só passaram a conceituá-la com maior exatidão após a abdicação. De toda forma, os termos "república" e "federação" serviam muito mais como argumentos para pautar ações no campo da luta política do que categorias cristalizadas. O lugar de onde partiam e as pessoas que as propugnavam traziam, no juízo moderado, mais incertezas que soluções, além de remontarem a uma velha e polêmica discussão sobre a organização política do Império. A ideia de que o sistema federativo e a reforma constitucional seriam meios para uma revolução e não fins concretos e juridicamente assentados pode ser um elemento importante para pôr às claras porque a maioria dos moderados tardou a aceitar ambas as reivindicações. Além de ser um argumento retórico circunstancial de condenação à prática política dos exaltados, a negação desses pontos poderia significar, também, certa apreensão por parte dos moderados do que estaria por trás de uma eventual reforma com base na federação. Afinal, o termo era equívoco e sua adequação ao regime monárquicoconstitucional, incerta. Isso sem contar que parte dos moderados acreditava que a Constituição de 1824 era suficientemente boa se fosse bem executada. Guardava defeitos, mas não tão graves a ponto

\footnotetext{
${ }^{23}$ BASILE, Marcello. Projetos de Brasil e construção nacional na imprensa fluminense (1831-1835). In: FERREIRA, Tania Maria Bessone da C.; MOREL, Marco; NEVES, Lucia Maria Bastos Pereira (org.). História e imprensa: representações culturais e práticas de poder. Rio de Janeiro: DP\&A/ Faperj, 2006. p. 60-93.

${ }^{24}$ OLIVEIRA, Carlos Eduardo França de. Poder local e palavra impressa... Op. Cit.
} 
de demandarem uma modificação imediata.

O surgimento de jornais ditos exaltados tornou o debate político mais plural, sobretudo no próprio campo liberal. Em comparação aos moderados, os exaltados não compunham uma frente parlamentar nem se alojavam na cúpula da magistratura. Eram em sua maioria profissionais liberais, funcionários públicos, militares e pequenos e médios comerciantes, como o boticário Ezequiel Corrêa dos Santos, o publicista Antônio Borges da Fonseca e o tipógrafo Paula Brito. E, ao contrário dos moderados, não questionavam somente aqueles que estavam no governo e a forma como governavam, mas as próprias bases jurídico-administrativas do novo Estado, realimentando um debate que era candente desde as discussões ocorridas no plenário da Constituinte de 1823. Ao enfatizar a necessidade das reformas constitucionais, a eficácia dos princípios federativos e a importância de ampliarem-se as bases de participação política, os exaltados apartaram-se dos moderados, criticando-os inclusive pelo seu caráter "retrógrado" e "estacionário", o que operou uma fissura no campo liberal, alargando a discussão via impressos para além da antinomia entre liberalismo e despotismo.

Porta-voz dos liberais moderados em São Paulo, o jornal O Farol Paulistano publicou, a partir de dezembro de 1830, uma série de artigos em que objetava a feitura de reformas na Carta de 1824, até então uma bandeira identificada exclusivamente aos exaltados. Embasado na ideia de que o cumprimento da Constituição era a chave para o alcance de um bom governo, O Farol Paulistano foi categórico no seu repúdio a qualquer alteração do texto constitucional brasileiro, tido como suficiente, se bem executado, para a "felicidade do Brasil". Juntamente com a salvaguarda da Constituição, que deveria ser seguida à risca para não colocar em perigo a segurança da monarquia constitucional representativa, O Farol Paulistano buscou minorar a força dos exaltados que, na sua opinião, estariam reduzidos a alguns "poucos homens" situados no Rio de Janeiro ${ }^{25}$.

Esforços como este não conseguiram deitar por terra o fortalecimento de vozes contrárias. Dois fenômenos ocorridos no âmbito da imprensa periódica paulista indicam uma expansão dos ideais exaltados em São Paulo - notadamente na capital - nesse período, sendo o primeiro deles o surgimento, em janeiro de 1831, de A Voz Paulistana, periódico redigido pelo estudante do Curso Jurídico de São Paulo Francisco Bernardino Ribeiro ${ }^{26}$ e cujas propostas se alinhavam ao ideário exaltado. O segundo foi o processo de radicalização do discurso de O Observador Constitucional. Se, entre 1829 e 1830, o periódico manteve uma postura moderada, após a abdicação, houve um deslocamento de sua orientação político-ideológica para a ala exaltada dos liberais.

A folha de Bernardino Ribeiro questionou algumas das assertivas comumente pronunciadas pelos moderados paulistas, tal como a de que a província de São Paulo era constituída por grupo coeso política e ideologicamente. A Voz Paulistana passou a ostentar pontos até aquele momento refutados ou propositadamente pouco comentados por O Farol Paulistano e O Observador Constitucional, como a reforma da Constituição, o sistema federativo e, em alguns momentos, a república. Seu estilo combativo lhe rendeu constantes citações por parte dos periódicos exaltados da Corte, a exemplo de O Repúblico e de A Nova Luz Brasileira.

O surgimento do novo jornal foi noticiado com reticência por O Farol Paulistano, o qual afirmou que "ser amante da pátria" não bastava para desempenhar um bom papel enquanto redator. Este reprovou algumas das afirmações da nova folha, sobretudo aquelas que insinuavam estar a província de São Paulo cindida politicamente, e que dentro dos próprios liberais haveria discordâncias. A folha de Costa Carvalho contestou, ainda, o julgamento de A Voz Paulistana no tocante à hipotética existência de um "estilo ditatório" nos jornais paulistas, que tentariam manipular a "opinião pública" da província ${ }^{27}$. No mês seguinte, publicou um artigo em defesa da federação, afirmando que esta era mirada pela maioria dos cidadãos de todo o Império.

A preocupação de $O$ Farol Paulistano em combater A Voz Paulistana aumentou gradativamente e o sistema federativo recebeu pela primeira vez um tratamento mais contundente. Para isso, publicou um excerto sobre a federação de François Guizot, futuro primeiro-ministro na Monarquia de Julho (1830-

\footnotetext{
${ }^{25}$ Farol Paulistano, n. 431, 21/12/1830.

${ }^{26}$ Francisco Bernardino Ribeiro (1815-1837) também era poeta e ajudou a fundar a Revista da Sociedade Filomática, órgão oficial da Sociedade Filomática, fundada em São Paulo em 1832. Mais tarde seria lente de Direito do Curso Jurídico de São Paulo.

${ }^{27}$ Farol Paulistano, n. 439, 15/01/1831.
} 
1848). De acordo com o excerto traduzido, o sistema federativo era o mais difícil de estabelecer, visto que consistia em "deixar a cada localidade, a cada sociedade particular, toda a porção de governo que lhe pode tocar, e em não lhe tirar senão a porção indispensável para manter-se a sociedade geral, para a levar ao centro dessa mesma sociedade, e constituí-la sob a forma de governo central". Aparentemente o mais simples, o sistema federativo seria na realidade o mais complexo, visto que para conciliar os interesses locais com os do governo central requeria-se um alto grau de "razão", "moralidade" e "civilização" de uma sociedade. Estágio que, no entender de O Farol Paulistano, o Império brasileiro ainda não atingira, atitude que recolocava o argumento da incompatibilidade entre a sociedade brasileira e as "instituições mais avançadas". Mais cauteloso foi O Observador Constitucional que, a partir de março, começou a flertar com o tema. Para seu redator, o problema residia no tratamento da questão, pois muitos dos defensores da federação estavam detratando aqueles que não a desejavam, o que configuraria uma injustiça para com homens que sempre estiveram à frente das "fileiras liberais". Ainda segundo o redator, esse tipo de conduta desagregaria os liberais, colocando em risco a estabilidade política do Império ${ }^{28}$.

Mesmo com o aumento de vozes discordantes, O Farol Paulistano reiterou sua posição contrária à reforma constitucional, argumentando que a Carta de 1824 continha elementos tão ou mais liberais do que aqueles presentes na Charte de 1830, isto é, no texto constitucional elaborado pelos liberais franceses após a queda de Carlos X e com base na revisão da Constituição da França de $1814^{29}$. De acordo com o redator de $O$ Farol Paulistano, questões que foram objeto da revisão presidida pelos liberais franceses - tais como a liberdade religiosa, a idade mínima para o voto, a responsabilidade dos ministros e a criação de uma guarda nacional - eram asseguradas pelo texto constitucional brasileiro, afastando a necessidade de ele ser metamorfoseado. O processo de institucionalização dos conselhos gerais foi inclusive considerado pelo redator como exemplo da amplitude de liberdades oferecida pela Carta de $1824^{30}$.

\section{Abdicação e mutações políticas na imprensa paulista}

A bibliografia pouco diverge quanto à distribuição de forças desencadeada pela abdicação e pelo advento da Regência, talvez pelo fato de que a divisão tripartite entre moderados, exaltados e caramurus tenha sido forjada pelos próprios contemporâneos, o que supostamente confere maior legitimidade de uso dessas terminologias ${ }^{31}$. O problema está em tomá-las como algo previamente dado e não como construções cujo sentido só é possível de apreender no decorrer da luta política. Sua utilização deve ser precedida, portanto, pela constatação de que por mais que remetessem a postulados teóricos sobre a organização do Estado e da sociedade, esses termos eram inexoravelmente fluidos e, por isso, a coerência programática pesava menos do que a função política. Isso não invalida as matrizes de pensamento às quais se filiavam nem as diferenças ideológicas existentes entre eles, tampouco reduz a política ao circunstancial e ao contingente. Mas é preciso tomar como ponto de partida que moderados, exaltados e caramurus eram grupos heterogêneos e dotados de constante mutabilidade, o que obriga o historiador a evitar descrições estanques.

Outro ponto a ser sublinhado é o de que, muito embora seja na maior parte das vezes creditada pela bibliografia à câmara temporária e ao debate político travado na Corte fluminense, particularmente na imprensa periódica e nas sociedades políticas ali nascidas, a partição entre moderados, exaltados e caramurus foi constituída pari passu no Rio de Janeiro e nas províncias, dado fundamental que não pode ser ignorado. A profusão de panfletos, jornais, petições e representações que circulavam dentro das províncias, sobretudo do centro-sul, e destas para o Rio de Janeiro, ajudou a estabelecer, para além de alianças políticas circunstanciais, um arcabouço reflexivo sobre teoria e prática política, um vocabulário comum, a necessidade de se refletir sobre noções de grupo - como a de partido - e, por fim, um horizonte de expectativa ${ }^{32}$ entre setores dispersos pelo Império em torno de projetos de Estado

\footnotetext{
${ }^{28}$ Farol Paulistano, n. 454, 26/02/1831; Observador Constitucional, n. 131, 04/03/1831.

${ }^{29}$ ROSANVALLON, Pierre. La monarchie impossible. Les Chartes de 1814 et de 1830. Paris: Fayard, 1994.

${ }^{30}$ Farol Paulistano, n. 460, 08/03/1831.

${ }^{31}$ BOURDIEU, Pierre. O poder simbólico. Lisboa: Difel, 1989.
}

${ }^{32}$ KOSELLECK, Reinhart. "Espaço de experiência" e "horizonte de expectativa": duas categorias históricas. In: Idem. Futuro passado: contribuição à semântica dos tempos históricos. Tradução de Wilma Patrícia Maas e Carlos Almeida Pereira. Rio de Janeiro: 
e nação mais ou menos consensuais dentro de cada posicionamento. É necessário ter cuidado, todavia, para não se transpor para as províncias a realidade da capital do Império, onde a distinção entre moderados, exaltados e caramurus se delineou de forma mais acentuada, sobretudo se pensarmos em termos de atuação política. É tentador, mas arriscado caracterizar o debate público - sobretudo aquele encabeçado pela imprensa - tendo como parâmetro o Rio de Janeiro, onde o espaço público era mais complexo e diversificado. O importante é compreender que a própria ideia do que seria um moderado, por exemplo, deu-se por meio da troca de experiências, vocabulários e influências de políticos dentro e fora da capital, que batalharam para se apresentar como membros de um grupo homogêneo e consensual, quando na realidade ofuscavam, por necessidade de sobrevivência política, divergências programáticas, regionais e pessoais.

A notícia da abdicação de d. Pedro chegou depressa em São Paulo. O Farol Paulistano publicou um resumo dos antecedentes que culminaram na saída do monarca, sem ocultar seu contentamento com o acontecido. Em harmonia com os articuladores da Regência, a folha dirigida por Costa Carvalho alertou para a necessidade de "calar todos os partidos", depositar "toda a confiança na Assembleia Geral" e obedecer às "Leis" e às "Autoridades", numa clara tentativa de cooptar o público leitor para o projeto político que se instalara no Rio de Janeiro. Em paralelo, a ênfase na manutenção da "ordem", do "juízo" e da "união" demonstrava o receio de que alterações mais profundas, almejadas pelos liberais exaltados, reverberassem entre os paulistas. Em tom de júbilo, o redator de O Observador Constitucional noticiou a retirada de cena de d. Pedro, retratado como o "causador de todos os males" e o mantenedor da "tirania no Brasil". Além de pleitear o destaque do Parlamento, o que de certa forma restringia a participação de outras esferas de poder no encaminhamento da situação, o redator desse periódico clamou para que ninguém emitisse "qualquer opinião" que se desligasse do "regime jurado". A defesa do sistema monárquico-constitucional prescindia, portanto, de qualquer atitude a ser tomada futuramente.

Diferentemente de províncias como Rio de Janeiro e Minas Gerais, São Paulo não viu surgirem periódicos afinados com os caramurus, o que não significa que inexistissem homens simpáticos a eles. Embora fuja do escopo deste artigo, vale observar que as listas eleitorais da província de São Paulo do início do período regencial evidenciavam uma geografia política mais complexa do que a imprensa moderada propalava. Enquanto os partidários da Regência e da moderação mantinham sob controle colégios eleitorais das regiões do oeste paulista produtoras de cana-de-açúcar ou associadas à atividade pecuarista (Itu, Constituição, Sorocaba, Atibaia e Itapetininga) como seu maior reduto, setores da oposição caramuru concentravam seus votos em Santos e localidades litorâneas sob sua influência (Iguape, Paranaguá), além de algumas vilas distantes da capital paulista, como Areias, no Vale do Paraíba. Os demais colégios vale-paraibanos pendiam para os candidatos moderados, mas sem a preponderância característica das vilas do oeste paulista. O colégio de São Paulo, o de maior peso da província, assistiu a disputas parelhas, evidenciando mais uma vez que a capital paulista estava longe de ser uma área demarcada de influência moderada, ao contrário do que cansaram de propalar os jornais moderados paulistanos ${ }^{33}$. É possível supor que a ausência de periódicos caramurus tenha decorrido de alguma estratégia que enxergasse na criação de jornais um elevado custo político, já que o fortalecimento dos moderados paulistas após a abdicação foi visível.

Da sua parte, O Farol Paulistano continuou centrando fogo em A Voz Paulistana que, por sua vez, havia sugerido, logo após o 7 de abril, a proclamação de uma república federativa no Brasil. Para o redator de $\mathrm{O}$ Farol Paulistano, a maioria dos paulistas nem sequer aprovava as "doutrinas federativas" e muito menos a república. Tanto a federação como as reformas na Constituição seriam "meros pretextos" utilizados por aqueles que as defendiam para levarem adiante uma "revolução", raciocínio este que encontraria explicação em dois motivos. Primeiramente, a "mania da federação" supostamente nascera na capital do Império, onde a ideia de que se as províncias ganhassem maior independência seria um contrassenso, visto que o centro da nação tenderia a organizá-las em torno de si. Além disso, aqueles que pugnavam pela federação em São Paulo não seriam paulistas legítimos, mas indivíduos oriundos de outras partes do Império. No número subsequente, O Farol Paulistano asseverou que seus

Contraponto/PUC-Rio, 2006. p. 305-308.

${ }^{33}$ OLIVEIRA, Carlos Eduardo França de Oliveira. Construtores do império, defensores da província: São Paulo e Minas Gerais na formação do estado nacional e dos poderes locais, 1823-1834, 1ª ed. Porto Alegre: PUCRS, 2017. cap. 3. 
artigos vinham demonstrando que a vereda para o "sistema unitário" era a "monarquia constitucional" e que, nesse sentido, tanto fazia a província de São Paulo ser governada por um paulista ou por um baiano. De acordo com o mesmo redator, os "federalistas" estariam "dominados por um provincialismo exclusivo". Tais artigos geraram controvérsia dentro e fora de São Paulo. Em Minas Gerais, O Pregoeiro Constitucional escreveu que as considerações da folha paulista mereciam "rigidíssimas censuras", sobretudo aquela que associava erroneamente federação com revolução. $O$ redator mineiro também retorquiu a afirmação de que inexistissem paulistas que ansiassem a federação ${ }^{34}$.

Embora até aquele momento nunca houvesse compactuado com o sistema republicano, tampouco defendido a federação ou qualquer tipo de alteração na Constituição, O Observador Constitucional saiu em defesa de $A$ Voz Paulistana num artigo que apelava para reivindicações políticas de fundo e que passariam pelas reformas. Iniciava-se, a partir desse momento, uma viragem no discurso da folha fundada por Líbero Badaró que progressivamente passou a aderir à necessidade da feitura de alterações na Carta de 1824 e da implementação de um sistema federativo:

Para que falar com tanta acrimônia contra as reformas da Constituição, e mesmo contra a federação? Poderá São Paulo trilhar por si uma estrada diferente da que trilharam o Rio de Janeiro e mais províncias? Não é para aquele que todas têm voltado as suas vistas? Sabe-se já se o Rio de Janeiro não quer as reformas e a federação? (...) Vimos aparecer um artigo no Farol n ${ }^{\circ} 476$, o qual no meio de muitas opiniões absurdas trouxe consigo o gérmen da desunião e do descontentamento. Esforça-se o autor do artigo para provar que a federação e as reformas na Constituição são em muito menos pretextos para a revolução (...) Cremos que o voto geral não propende para que uma das reformas, ou ao menos nós não decidimos absolutamente por essa reforma, porém cremos também que nenhum brasileiro digno deste nome ousará opor-se a muitas que são necessárias na nossa Lei Fundamental, e ainda mesmo a tirar-se dela todos os elementos monárquicos preponderantes para os substituir por democráticos ${ }^{35}$.

As "razões" anteriormente apresentadas por O Farol Paulistano de que a federação e a reforma constitucional seriam pretextos para uma ação revolucionária foram reutilizadas em O Observador Constitucional como arma política. Ainda no mesmo exemplar, lançando mão de uma retórica sagaz, o redator deste inverteu a posição na qual O Farol Paulistano se colocara até aquele momento. De defensor da liberdade e da ordem, O Observador Constitucional imputou-lhe as qualidades de estacionário e desinformado, quer por ter confundido o clamor de reformas com "revolução", quer por ter afirmado que os simpatizantes da federação quase inexistiam em São Paulo. Ao final do artigo, o redator de O Observador Constitucional publicou um abaixo assinado por 92 paulistas que admitiam "com muito bom grado a todas as reformas Constitucionais (...) por meio do seu artigo 174". O protesto alastrou-se para outras províncias, como Rio de Janeiro e Minas Gerais, onde recebeu apoio ${ }^{36}$. Dentre os noventa e dois presentes no abaixo-assinado, apenas o conselheiro-geral e juiz de paz da capital paulista José Antônio dos Reis e o suplente Manoel Dias de Toledo ocupavam naquele momento cargos de proeminência na política provincial. Alguns deles assomariam na cena política mais tarde, como Fernando Pacheco Jordão, Mariano Rodrigues de Souza Mello e Martim Gonçalves Gomide e o próprio Manoel Dias de Toledo, auditor do Conselho de Guerra em 1833 e duas vezes presidente da província de São Paulo ${ }^{37}$.

Além de José Antônio dos Reis e Manoel Dias de Toledo, colegas de turma entre 1828 e 1831, outros onze estudantes do Curso Jurídico de São Paulo deixaram seus nomes no abaixo-assinado ${ }^{38}$. Embora ainda não apresentasse a importância que deteria na segunda metade do século XIX, o Curso Jurídico de São Paulo propiciou, em seus anos iniciais, um fórum de discussão de ideias jurídicas, políticas e artísticas, contribuindo para isso o ingresso de alunos e professores de diferentes partes do Império ${ }^{39}$. A própria categoria "estudante", atualmente associada à ideia de juventude, deve ser

\footnotetext{
${ }^{34}$ Farol Paulistano, n. 476 (19/04/1831) e 474 (23/04/1831); Pregoeiro Constitucional, n. 66, 11/05/1831.

${ }^{35}$ Observador Constitucional, n. 145, 29/04/1831.

${ }^{36}$ Estrela Marianense, n. 55, 06/06/1831.

${ }^{37}$ Ofício de 12/06/1833. Arquivo Público do Estado de São Paulo. Acervo Digital, Ofícios Diversos.

${ }^{38}$ Marcelino Ferreira Bueno, Jose Gaspar dos Santos Lima, Francisco de Assis Pupo, Antonio Manoel de Campos Melo e Emilio Paulo de Carvalho haviam se matriculado no Curso Jurídico em 1829, ao passo que Joaquim Otávio Nébias, João Manoel de Almeida Barbosa, Martim Gonçalves Gomide, Joaquim Inácio Ramalho, Ildefonso Xavier Ferreira, Antônio Rodrigues de Almeida Jordão e João Crispiniano Soares faziam parte da turma do ano de 1830. Cf. VAMPRÉ, Spencer. Memórias para a história da Academia de São Paulo. São Paulo: Saraiva, 1925. p. 102-165.
}

${ }^{39}$ NOGUEIRA, J. L. de A. A Academia de São Paulo. Tradições e reminiscências. São Paulo: Saraiva, 1977. 
relativizada para esse período. Ao lado de um Joaquim Otávio Nébias, nascido em 1811, faziam parte do corpo discente homens como Idelfonso Xavier Ferreira (1795-18??) e José Antônio dos Reis (1798-1876) que, por sua vez, eram contemporâneos de Manoel Joaquim do Amaral Gurgel (17971864) e Antônio Mariano de Azevedo Marques, também alunos do Curso Jurídico, representantes da moderação paulista. Os exaltados, diga-se de passagem, foram comumente associados pela imprensa moderada à juventude, numa tentativa de menosprezar sua força e ressaltar sua inexperiência política. Num artigo publicado antes da abdicação, o redator de $O$ Farol Paulistano afirmou que a maior parte das pessoas que defendiam as reformas da Constituição não sabia como era a política no "tempo antigo", por isso não conseguia medir os progressos obtidos com a execução da Carta de $1824^{40}$. Outros setores da sociedade paulista também estavam representados na lista de assinaturas, dentre eles militares, clérigos, negociantes, funcionários públicos e profissionais liberais.

$\mathrm{O}$ acirramento do debate em torno da reforma constitucional culminou na reestruturação do campo de luta política na imprensa periódica. O Farol Paulistano, que após a abdicação mantiverase firme no repúdio a qualquer alteração à Carta de 1824, foi aderindo a algumas das reivindicações anteriormente associadas aos exaltados para rechaçar a pecha de "antirreformista" 41 e perder espaço no debate. No início de maio, O Farol Paulistano publicou um artigo em que alterava sua argumentação em favor das reformas. Sobre o sistema federativo afirmou a folha de Costa Carvalho:

[...] entendemos muito pouco da Federação do $\mathrm{n}^{\circ} 17$ da Voz, bem que muito nos agrade, pois com ela evitaremos a separação das Províncias, conservaremos a integridade do Brasil, e faremos uma só Nação livre e respeitável. É a primeira vez que vemos na $V o z$ alguma explicação do que é Federação; não nos pareceu mal ${ }^{42}$.

Segundo O Farol Paulistano, as alterações deveriam ser feitas com base no artigo 174 da Constituição, solução aventada por parte dos moderados mineiros e por O Observador Constitucional, que passou, aliás, a constituir referência para o jornal na condução do debate em torno da reforma. Além disso, o redator de $O$ Farol Paulistano acenou para a possibilidade de se retirar do Poder Moderador o seu direito de veto absoluto das decisões do Legislativo, ingerência que, em sua opinião, estava muito mais próxima das "velhas monarquias da Europa" do que de um estado liberal. Para o mesmo redator, o artigo 164 da Constituição também merecia uma revisão de conteúdo. De acordo com o parágrafo segundo do referido artigo, caberia ao Supremo Tribunal de Justiça "conhecer dos delitos e erros de ofício que cometerem os seus ministros, os da relação, os empregados no corpo diplomático e os presidentes das províncias", o que significaria, no entender do redator, a cristalização de um "juízo privativo" facilmente corruptível e que privilegiaria homens dotados de grande poder. O artigo 90 sobre o processo eleitoral no Império também demandava ajustes. O sistema de eleições indiretas trazia consigo "alguns inconvenientes", como o de deixar para um número muito reduzido de pessoas a escolha efetiva de seus políticos. E sentenciou: "Se o Governo é representativo, se a Nação é que nomeia seus representantes, ela que os nomeie de fato" ${ }^{43}$.

O fato de O Farol Paulistano ter aderido a algumas propostas de reforma desguarneceu-o perante seus adversários. A Voz Paulistana criticou a mudança de opinião e acusou-o de entrar em "contradição" com seus exemplares anteriores. Diante disso, afirmou esperar que O Farol Paulistano não voltasse a modificar suas considerações, a fim de evitar futuras incoerências. A folha de Costa Carvalho defendeu-se das acusações afirmando que sempre desejara alterações na Constituição e que "sem intenção alguma" seus artigos acabaram produzindo uma ideia contrária. Com relação à "mudança de opinião", o redator contestou a argumentação de A Voz Paulistana e, em certa medida, para justificar as supostas alterações ocorridas em seu discurso, afirmou que "sempre" revisaria o conteúdo de seus artigos caso "boas razões" o convencessem ${ }^{44}$.

A mudança de opinião de O Farol Paulistano nada tinha de episódica. Ela coincidia com o surgimento do tema da reforma na Câmara dos Deputados, quando da abertura da sessão de $1831 \mathrm{em}$

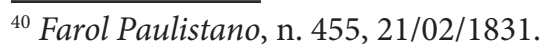

${ }^{41}$ Mentor das Brasileiras, n. 61, 1831.

${ }^{42}$ Farol Paulistano, n. 482, 03/05/1831.

${ }^{43}$ Farol Paulistano, n. 484, 07/05/1831.

${ }^{44}$ Farol Paulistano, n. 486, 14/05/1831.
} 
maio. Se, de um lado, a vacância do trono foi entendida pelos moderados como a chance definitiva de apoderarem-se do estado, de outro, havia a possibilidade de reestruturá-lo político-juridicamente conforme seus interesses. Mas a questão era mais intrincada do que isso, visto que a instabilidade gerada pela abdicação ampliou o espectro social de atuação política ou, melhor dizendo, alargou o horizonte de demandas por transformações na estrutura do Estado. A pressão advinda primordialmente dos setores exaltados fez com que os moderados, a essa época maioria na Câmara, trouxessem para si a direção das alterações que seriam feitas na monarquia brasileira, dentro da legalidade e com base na Carta de $1824^{45}$. Mesmo em São Paulo, onde a atuação dos exaltados foi mais restrita em comparação a outras províncias, agitações que punham em xeque a Regência passaram a ocorrer com maior frequência, exigindo dos moderados uma postura mais pragmática e menos irredutível com algumas das bandeiras exaltadas.

Um dos primeiros deputados a sugerir modificações no texto constitucional foi o baiano Antônio Ferreira França, que havia sido eleito pela sua província natal na legislatura anterior. No início de maio de 1831, surgiu uma discussão em torno da criação de um Conselho Geral na província do Rio de Janeiro, mas que foi barrada por inconstitucionalidade, pois o artigo 72 da Carta de 1824 proibia a instalação daquele órgão na capital do Império. Segundo Ferreira França, por este e outros motivos que se resumiam à ampliação de poderes da esfera provincial -, era necessário alterar a Carta de 1824 para torná-la "perfeita" 46 . No dia 6 do mesmo mês, José Cesário de Miranda Ribeiro, deputado por Minas Gerais, apresentou um requerimento cujo objetivo era criar uma comissão especial encarregada de propor as reformas constitucionais de acordo com os artigos 175, 176 e 177 da Carta de 1824. Isto é, primeiro seriam discutidos os artigos a serem alterados; depois, as alterações passariam pelas duas Casas e seriam sancionadas na forma de lei; esta, por fim, serviria como sustentáculo para a discussão a ser feita pela legislatura seguinte, a única com poderes efetivos de aprovar a reforma constitucional em definitivo ${ }^{47}$.

Parcela dos deputados censurou tais propostas sob o pretexto de que trariam instabilidade ao regime estabelecido. Os baianos Lino Coutinho e Rebouças, além do pernambucano Luiz Cavalcanti, prognosticaram que eventuais alterações na Carta de 1824 poderiam causar a desagregação entre as províncias, pois ressaltariam os poderes locais. Ainda que cercada de celeuma, a proposta de Miranda Ribeiro foi aprovada por grande maioria. Para a comissão incumbida de apresentar o conjunto de reformas foram eleitos o próprio Miranda Ribeiro, Paula Sousa e José da Costa Carvalho. Na época, o redator de $O$ Observador Constitucional sugeriu que as câmaras municipais apresentassem à Assembleia Geral os pontos que julgassem essenciais no encaminhamento da reforma constitucional, numa tentativa de minar a exclusividade da discussão do Parlamento, estendendo-a a outras esferas de poder representativo ${ }^{48}$. Esse tipo de recomendação foi rejeitado pela maioria dos deputados que defendiam o monopólio do Legislativo na condução de assuntos de maior envergadura política, como a reforma. Não é de estranhar, portanto, que, pouco tempo depois, o deputado fluminense Antônio de Castro Alves condenasse as câmaras paulistas de Itu e São Paulo por terem "exorbitado suas atribuições", isto é, por terem "representado [à Câmara dos Deputados] sobre coisas políticas" quando das excitações ocorridas na capital do Império em julho de $1831^{49}$.

Enquanto a comissão parlamentar elaborava o projeto de reforma, a imprensa aprofundava os debates sobre a federação. Recuperando a concepção hamiltoniana de sistema federativo, o redator de O Observador Constitucional assinalou que este seria um conglomerado de associações dotadas de autonomia, mas subordinadas a um governo central, estrutura esta que o Império possuiria em certo grau, graças à existência dos conselhos provinciais. Mas para aperfeiçoar a federação era imperativo incrementar os "direitos" das províncias, ou seja, retirar do governo central aqueles de "soberania interna" e deixar-lhes somente os de atribuição "externa". Tomando como exemplo os Estados Unidos, o redator de O Observador Constitucional sustentou que o alargamento da autonomia provincial não

\footnotetext{
${ }^{45}$ BASILE, Marcello. “O negócio mais melindroso": reforma constitucional e composições políticas no Parlamento regencial (18311834). In: NEVES, Lúcia Maria Bastos Pereira das (org.). Livros e impressos: retratos dos Setecentos e dos Oitocentos. Rio de Janeiro: Eduaerj, 2009. p. 185-209.

${ }^{46}$ SLEMIAN, Andréa. Op. Cit., p. 231-232.

${ }^{47}$ Anais do Parlamento Brasileiro. Câmara dos Deputados, sessão de 06/05/1831.

${ }^{48}$ Idem; Observador Constitucional, n. 152, 27/05/1831.

${ }^{49}$ Anais do Parlamento Brasileiro. Câmara dos Deputados, sessão de 04/07/1831.
} 
geraria desagregação, visto que as províncias, preocupadas com seus negócios, vislumbrariam na "união" com as demais um mecanismo para salvaguardar a sua integridade e a de todo o Império:

Nada mais lato do que a palavra Federação. Ela se pode definir em geral um complexo de pequenas Associações ligadas por um governo Geral. Ela é suscetível de graduações, e pode se dizer tanto mais perfeita quanto cada uma d’essas pequenas Associações adquire, ou possui maior soma de direitos, mais imperfeita quanto elas os possuem em menor número.

Uma Nação dividida em Províncias, ou estados etc. tendo cada uma d'estas um Governo, que as administre, embora seja ele dependente em todo d'um Governo Central, esta Nação possui contudo o Governo Federativo; pois que ela não é, senão uma coleção de associações, bem que com muito poucos direitos de ser.

O Governo atual do Brasil é um Governo Federativo; e um Governo Federativo algum tanto já aperfeiçoado; pois que as Províncias têm seus Conselhos Provinciais, que possuem uma soma bem que diminuta de direitos; podendo tratar de certos negócios particulares etc.: e a proporção que estes Conselhos, ou Associação, que compõem as Províncias, tirarem das mãos do Governo Geral mais direitos para aumentá-la, temos que a Federação se vai aperfeiçoando; tem que com a vulgarização de princípios, com o aumento de população, e civilização toque a sua perfeição; isto é, subtraia ao Governo Geral todos os direitos que constituem a sua Soberania interna, deixandolhe só os de sua Soberania externa. É a este por excelência, que se chama o Governo Federativo; que se pode definir

a reunião de muitas pequenas Associações, que tem o seu Governo particular, ligadas por um Governo Geral.

D’aqui já mui bem poderão ver nossos leitores com quanta sem razão se tem argumentado no Brasil contra a doutrina da Federação. A questão não pode versar sobre o ponto de que devera ou não ser o Governo do Brasil Federativo, sim se a Federação, que nós já temos, deverá ou não ser mais aperfeiçoada: isto é se as Províncias deverão, ou não ter maior soma de direitos (...) Diremos agora alguma coisa a respeito do Governo Federativo em geral. É ele bom? Para o provar bastará só lembrarmo-nos, que é esse sistema de Governo, que tem feito a felicidade de um Povo, que hoje no mundo inteiro é olhado, como modelo das Sociedades bem constituídas. Embora se diga, que este sistema, dividindo um todo em muitas partes, e dando a cada uma d'elas as obrigações, que possuía o tempo, necessariamente deverá enfraquecê-lo; e que cada uma das partes perde então, por si também um todo; embora se diga também, que a rivalidade, resultado da independência é uma tal forma de Governo o gérmen da destruição; pois que cada uma das partes movida pelos seus interesses, tende a desobrigar-se do que se deve, e a separar-se da união, aonde julga haver um princípio, que a pretende escravizar. O Governo dos Estados Unidos tem mostrado que estes raciocínios não passam de meras conjecturas, ou mentalidades, e que na prática o contrário sucede.

A força que se diz, perde o todo pela divisão em várias partes, aumenta-se, pelo contrário, quando cada uma dessas partes interessadas na sua segurança considera que a sua força é na união; e que ela separada pode mais perder, pois que a união das outras tem força muito maior, com que possa subjugar ${ }^{50}$.

Assumir que a federação era "suscetível a graduações" tornava-a ainda mais ambígua, passível de diferentes reapropriações, sendo justamente essa plasticidade do termo que permitiu aos moderados incorporá-la ao seu discurso. A ideia de que o Brasil estaria dotado de um "governo federativo", por exemplo, agradou ao redator de $O$

Farol Paulistano, que teceu considerações sobre o artigo publicado em O Observador Constitucional:

O Observador (...) traz no seu N. 158 um artigo acerca do Governo Federativo que é digno de ser lido por todos aqueles que de boa-fé desejam o melhoramento das nossas instituições sociais. Sobretudo é digna de notar-se a seguinte proposição - o Governo atual do Brasil é um Governo Federativo, e um Governo Federativo algum tanto já aperfeiçoado - e da qual segue a mostrar como é que as nossas Províncias ganhando pouco a pouco direitos sobre o Governo Geral pelo que toca à sua administração interna, ir-se-á aperfeiçoando o sistema federal, até que as mesmas Províncias se constituam como Estados Independentes, relevando somente d'um centro comum pelo que toca aos negócios externos com as demais associações externas... ${ }^{51}$.

O cerne do artigo de $O$ Farol Paulistano era demonstrar, partindo da premissa apontada em $O$ Observador Constitucional, que o Brasil apresentava traços de um "Governo Federativo algum tanto já aperfeiçoado", que uma possível alteração no sistema monárquico-constitucional dar-se-ia "dentro da órbita Constitucional", ou seja, de forma gradual, ancorada juridicamente pela Carta de 1824 e sem a

\footnotetext{
${ }^{50}$ Observador Constitucional, n. 158, 27/06/1831.

${ }^{51}$ Farol Paulistano, n. 504, 30/06/1831.
} 
necessidade de uma "nova revolução", da convocação de uma "Assembleia Constituinte" ou da aplicação de um novo texto constitucional. Ao instrumentalizar o discurso de O Observador Constitucional a seu favor, o redator de $O$ Farol Paulistano argumentou, com o intuito de amainar as divergências entre moderados e exaltados, que a realização de reformas "pelos trâmites da Constituição" traria, futuramente, as garantias da "mais perfeita Democracia", sem grandes convulsões sociais. Artimanhas à parte, $O$ Farol Paulistano interrompeu suas atividades no próprio mês de junho ou início de julho. É provável que o crescimento da oposição ao periódico tenha esmaecido sua imagem e colocado em perigo a de seu proprietário - a essa altura Costa Carvalho era regente -, de modo que o encerramento das atividades do jornal possa ter sido uma estratégia de defesa, mesmo porque o jornal voltaria a ser publicado sob novo nome - O Novo Farol Paulistano - cerca de um mês depois.

O Observador Constitucional deu prosseguimento à sua argumentação no número seguinte do jornal e enfatizou que, num sistema federativo, a "civilização" e a "indústria" do Império teriam propensão a aprimorar-se, pois a existência de associações autônomas dinamizaria o funcionamento de um Estado que vinha se mostrando impotente diante da sua imensidão e da falta de recursos para gerir as províncias equitativamente. Mas, a despeito de defender a federação, o redator reconheceu que o Brasil não teria os "homens" e a "moralidade" necessários para que fosse instalada uma "Federação Republicana", isto é, um regime republicano, distanciando-se, nesse ponto, da ala mais radical dos "exaltados", que via na república uma solução imediatamente viável para o Brasil. Para o mesmo redator, o percurso a trilhar seria, portanto, o de aquilatar o sistema federativo, o que na prática se resumiria no aumento de poderes das províncias:

Também que esta forma de Governo é a mais própria para o desenvolvimento da civilização, e da indústria, quem o poderá duvidar? Em um estado imenso, onde um só centro de poder vigia os interesses d'um Povo, a sua influência fraca fracamente favorece a indústria, e a civilização dos pontos distantes d’esse centro; e a indústria, e a civilização encontrando demora nos socorros, que se-lhes devem prestar retardar-se em seu desenvolvimento. Além disso, os diversos pontos do Estado, fiados no igual direito, que eles têm a proteção do centro, descansam, e quase nunca trabalhão por adquirir vantagens, em que excedam uns aos outros: com isto a indústria se demora, a civilização se retarda só a indolência ninguém ignorará. O desacorçoamento também aí aparece. As contribuições, e tributos, que pesam sobre o povo por nenhum bem visível são suavizados. Somas e somas saem de diversos pontos, e elas sendo absorvidas pelo Governo central, uma obra, uma coisa qualquer não aparece, com que ao menos o triste povo se console de as ter aumentado com suas fadigas e suores.

Ainda isto não é tudo: as autoridades, distantes desse Poder, que as tem enviado a esses pontos remotos, certas de que as queixas de suas arbitrariedades serão pela distância mal ouvidas do Poder Central, desenvolvem, e apresentam sem rebuço todo o seu mau humor. Debalde um povo levanta suas vozes, elas se perdem no imenso espaço que o separa do Poder; com isto essas Autoridades redobram seus furores, em um povo que tem inutilmente clamado por justiça tendo tido por resposta o silêncio, ou franqueia, e se larga ao furor dos déspotas, ou insurge por livrar-se da opressão: em qualquer dos casos seus interesses são atacados, ele deve perder.

Tudo ao contrário sucede nos Governos Federativos. Este Governo não sendo senão uma grande Sociedade composta de muitas pequenas Sociedades, que tem cada uma seu Governo particular, e que são todas ligadas por um governo Geral, apresenta todas as vantagens, e presta todos os socorros, de que a civilização, e o desenvolvimento das faculdades humanas necessitem. Nele um braço protetor acompanha todo o Cidadão: as suas instruções são

lhe pagas, sem que ele saia o liminar de sua casa.

O indiferentismo, e indolência aí não reinam. Apesar de ter direito a exigir do Poder Geral a mesma Proteção, os diversos pontos da união observam, e conhecem, que eles serão tanto mais felizes, quanto mais trabalharem para o ser. A emulação não tarda a aparecer; e ela, sendo o móvel das grandes ações, traz consigo a prosperidade dos Estados. Aparecendo ela faz prodígios; os homens, movidos por um interesse imediato é seus trabalhos; aplicam todos os seus esforços para adquirirem vantagens os de um sobre os de outro ponto: uma luta então entre todos se levanta, e em resultado todos promovem a civilização, a indústria, a felicidade de sua Pátria: e no meio desta luta, quando no interno de cada um dos Pontos todos se aplicam a promovê-las, o Governo Geral como colorado em uma elevada guarita vigia os interesses de sua grande família, defende-a do inimigo extenso, alimenta em todos os pontos a alma vivificadora das Sociedades, sustenta-lhes a Liberdade.

Porém, se tudo isto é certo não o é menos, que nesta mais, que em qualquer outra forma de Governo se tem necessidade de homens instruídos, e que sejam capazes de dirigir os negócios de sua Pátria; que nesta mais, que 
em qualquer outra forma de Governo se necessitam de bons costumes, e de uma moralização perfeita na massa da população. Terá já o Brasil estes homens? Não. Terá já o Brasil esta moralização? Não. Se achará já o Brasil em um estado de civilização capaz de formar uma Federação Republicana? Não.

[...] Esta substituição porém se irá operando pouco a pouco, e a proporção que homens novos, e hábeis apareçam; ela não levará muitos anos; muito deve adiantar-se nestes seis, ou sete. N’este intermédio pode muito aperfeiçoarse a moralização, e bons costumes do Povo, pois que os tendo, como devemos esperar, o Governo, aquele, que sempre participa de suas qualidades os terá também.

É só quando poderemos ser perfeitamente Republicanos, é só quando a nossa Federação poderá talvez ser ao todo aperfeiçoada.

Si hoje não podemos pois a ter tal, tenhamo-la naquele grão, que é compatível com a nossa civilização, e costumes; isto é, demos mais direitos as Províncias, mais atribuições as Assembleias Provinciais, tornando aquelas mais independentes do Poder Geral. Isto tem mostrado querer fazer a Câmara dos Srs. Deputados; com isto podemos contar.... ${ }^{52}$.

Com este artigo e o anterior, O Observador Constitucional definiu com maior clareza seu posicionamento no tocante à reforma constitucional e à federação. A despeito do caráter sinuoso e fluido do debate travado pelos jornais da época, é possível sugerir que O Observador Constitucional distinguiu-se entre o multifacetado campo político dos exaltados por meio da defesa de uma monarquia federativa onde as províncias teriam uma relativa independência do governo geral. A ideia de que fossem conferidas "mais atribuições" às assembleias provinciais seria o ponto nevrálgico da reforma constitucional a ser feita com base na Carta de 1824. Com isso, descartava-se a hipótese da implantação imediata de um sistema republicano/federativo à semelhança daquele em vigor nos Estados Unidos da América, tornando a solução republicana uma realidade a médio e longo prazos, quase teleológica, a ser conquistada aos poucos e em meio ao amadurecimento político da sociedade brasileira. É provável que por trás desse discurso legalista não houvesse uma recusa completa à implantação mais imediata da república, tal como sempre se colocaram os moderados. Nesse sentido, a manutenção do regime monárquico poderia ser uma arma retórica para irmanar-se do público leitor e mostrar-lhe, de forma indireta, as vantagens de um regime republicano. De todo o modo, a aceitação da monarquia constitucional era um ponto de congraçamento com os moderados e um elemento distintivo em relação aos exaltados mais radicais, expediente que foi adotado, vale dizer, por segmentos exaltados de outras partes do Império.

\section{O ardil moderado}

Em 9 de julho de 1831, circundada pelos acalorados debates fomentados pela imprensa, a comissão parlamentar incumbida de elaborar o projeto de reforma constitucional - composta pelos deputados Paula Sousa, Miranda Ribeiro e Costa Carvalho ${ }^{53}$ - apresentou seus trabalhos ${ }^{54}$. Principiava, a partir dali, um enfrentamento de forças na câmara baixa que se estenderia até pelo menos julho do ano seguinte, quando o malfadado golpe de 30 de julho impeliu um realinhamento entre os liberais. Para os moderados mineiros, paulistas e fluminenses, a linha de frente da oposição tinha nome e lugar de origem: era formada, sobretudo, por deputados das províncias do norte - Ernesto Ferreira França (Pernambuco), Holanda Cavalcanti (Pernambuco), Rebouças (Bahia) e Montezuma (Bahia) - e os Andrada, mais especificamente Martim Francisco (Minas Gerais) e José Bonifácio que, em 1831-1832, entrou como suplente na vaga de Honorato José de Barros Paim, deputado pela Bahia.

Em síntese, o projeto de reforma propunha mudanças que alterariam radicalmente a estrutura política do Império. Este seria transformado em uma associação conectada por laços federativos, embora se mantivesse o regime monárquico. Estava extinta a divisão do estado em quatro poderes, uma vez que o Moderador, derrogado, teria parte das suas atribuições (a serem ainda definidas) passadas para o Executivo. O Conselho de Estado foi igualmente abolido. No lugar do Senado vitalício estipulou-se outro eletivo, sem escolha por lista tríplice e com renovação da sua terça parte a cada legislatura. O tempo de duração das legislaturas seria diminuído de quatro para dois anos,

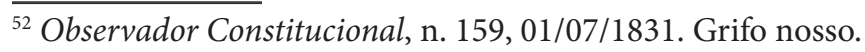

${ }^{53}$ Costa Carvalho deixou a comissão após tornar-se regente, em junho de 1831.

${ }^{54}$ Anais do Parlamento Brasileiro. Câmara dos Deputados, sessão de 09/07/1831.
} 
e as rendas do Império divididas em gerais e provinciais. Em substituição à Regência Trina, seria estabelecido o cargo de regente uno. Na esfera provincial, criar-se-iam, no lugar dos conselhos gerais, as assembleias provinciais, que teriam o poder de legislar sobre questões locais, inclusive sobre a estrutura orçamentária e tributária. Nos municípios seria criada a figura do intendente, com poderes executivos similares aos dos presidentes de província ${ }^{55}$. As modificações eram sensíveis, porém não nos esqueçamos de que duas das principais demandas reclamadas por alguns setores, sobretudo exaltados, não foram contempladas pelo projeto: a eleição do presidente de província e do comandante das armas pelos colégios eleitorais provinciais, pautas que vinham sendo ventiladas desde a Constituinte e que retornaram à baila quando do início do debate da reforma constitucional ${ }^{56}$.

Em São Paulo, O Observador Constitucional publicou uma apreciação da proposta apresentada pela comissão. Sua leitura corroborava as expectativas de parte dos exaltados que vislumbrava na reforma constitucional uma estratégia de amoldar, gradativamente, a política brasileira ao sistema republicano. Para o redator, o núcleo do projeto assentava-se na "divisão do Império em províncias", mais especificamente nas relações entre poder local e central. A extinção do Conselho de Estado e do Senado vitalício, bem como a criação das assembleias provinciais e do cargo de regente uno garantiriam à nação o "princípio Republicano das Representações populares, eletivas e temporárias", tornando o atual governo uma "monarquia de nome”, um estado transitório para a república:

[...] A Monarquia, em uma palavra está quase reduzida a uma Monarquia de nome, e que é fácil extinguir de todo, logo que os elementos, de que se compõem a nossa população, e outros diferentes, que lutam no meio do estado, se tornarem mais homogêneos, tornando-se uma massa mais volumosa, e compacta, que seja capaz de opor-se a invasões do arbitrário, e aos desvarios populares, que alguma coisa tem com este de comum; logo finalmente que conhecido melhor o ponto para onde todos nos devemos voltar, e caminhar, por meio das luzes d'aqui em diante adquiridas, que devem aumentar-se n'uma razão, e com uma rapidez espantosa, menor contrariedade apareça a respeito dos meios, que se devem empregar, para chegarmos com brevidade, ao ponto desejado dos Brasileiros, a uma Republica unida, fundada sobre bons estáveis, que não podem ser outras, senão a Liberdade, e a Justiça,

palavras sinônimas ${ }^{57}$.

Esperançosos com a reforma, os exaltados paulistas amargaram, entretanto, um importante revés. O Observador Constitucional cedeu espaço de seu jornal para a publicação de um artigo redigido por F. S. B. Garcia, um dos ex-redatores de A Voz Paulistana, a qual encerrara suas atividades dias antes, provavelmente porque seu último número seria levado a júri por ter "exorbitado as leis da decência e do decoro". Garcia defendeu-se daqueles que o fariam ir a julgamento, afirmando que a única coisa que fizera desde o início da publicação de $A$ Voz Paulistana foi utilizar a imprensa para divulgar "sua opinião", no caso a implantação da federação. No seu entender, a melhor alternativa para o Brasil após a abdicação do monarca teria sido a convocação de uma Constituinte, visto que "caindo o tirano imediatamente deveria cair tudo o que lhe pertencesse, e com muito mais razão a Constituição, obra sua". Esse caminho talvez evitasse as "cenas de tristeza" que vinham ocorrendo no Império ${ }^{58}$. $\mathrm{O}$ próprio Observador Constitucional, provavelmente em virtude da radicalização do seu discurso, teve que abandonar a Tipografia do Farol Paulistano e imprimir seus exemplares na Tipografia Patriótica, a partir de janeiro de 1832 .

Os moderados paulistas, por sua vez, revigoraram-se na imprensa. No início de agosto veio a público o primeiro número de O Novo Farol Paulistano, periódico redigido pelo aluno de Direito José Manuel da Fonseca e que tinha como principal colaborador o acadêmico João da Silva Carrão. A permanência do nome "Farol Paulistano" em combinação com o adjetivo "novo" pode ter sido uma tentativa em readequar a antiga folha dirigida por Costa Carvalho às circunstâncias daquele momento, reavendo sua pujança política. O jornal manteve o discurso moderado de seu antecessor, aspecto ressaltado com satisfação por periódicos como A Aurora Fluminense e O Universal. ${ }^{59}$ Ainda em 1831

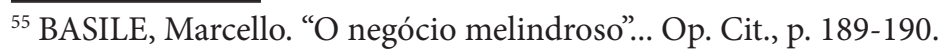

${ }^{56}$ FONSECA, Silvia Carla Pereira de Brito. Federalismo: a experiência americana de um conceito (1820-1835). Locus, vol. 36, n. 1, p. 85-116, 2013.

${ }^{57}$ Observador Constitucional, n. 165, 29/07/1831.

${ }^{58}$ Observador Constitucional, n. 171, 15/08/1831.

${ }^{59}$ Novo Farol Paulistano, n. 1, 06/08/1831; Universal, n. 646, 14/09/1831; Aurora Fluminense, n. 521, 24/08/1831.
} 
começaram a circular na capital paulista O Correio Paulistano, dirigido pelo negociante português José Gomes Segurado, e O Paulista, ambos moderados, mas de duração efêmera.

Em desvantagem na imprensa e vendo-se acuados diante dos moderados - que aos poucos tomavam para si as rédeas da reforma -, os exaltados paulistas organizaram-se na Sociedade Federal da cidade de São Paulo, fundada em dezembro 1831 e influenciada por suas congêneres baiana, fluminense, pernambucana e paraense, cujos objetivos eram "promover o andamento da Federação por todos os meios ditados pela razão e pela Justiça" e "auxiliar o Poder legislativo na consolidação do sistema federal". Criada após o desaparecimento da Sociedade Defensora da capital paulista, a Sociedade Federal conseguiu arregimentar nomes importantes dentro da sociedade paulistana, como o negociante Antônio da Silva Prado e o sargento-mor Joaquim José Silva. Em correspondência não oficial, o presidente da província Rafael Tobias de Aguiar confidenciou ao regente Costa Carvalho que a "tal Sociedade Federal" o preocupava e que se "[Antônio da] Silva Prado não tivesse aderido a ela outros também não o teriam feito"60.

Figuras como Cândido Gonçalves Gomide, José Gomes de Almeida e Manuel Costa de Almeida, anteriormente filiados à Sociedade Defensora de São Paulo, se ligaram à nova Sociedade. Alguns dos seus membros, a exemplo de José Antônio dos Reis, Manoel Joaquim Leite Penteado e Idelfonso Xavier Ferreira, haviam participado do abaixo-assinado publicado em O Observador Constitucional, pouco depois da abdicação, a favor das reformas na Carta de 1824. Diante disso, e a fim de coibir o crescimento da nova associação, Tobias de Aguiar sugeriu, embora sem sucesso, a proibição do ingresso de estudantes do Curso Jurídico na Sociedade Federal.

A Sociedade Federal de São Paulo foi alvo de acusações por parte dos periódicos moderados. $O$ Novo Farol Paulistano criticou-a por intervir em negócios concernentes à Assembleia Geral e rechaçou qualquer utilidade da nova Sociedade, visto que "as ideias federativas" haviam sido assimiladas com a "exatidão necessária", ou seja, tendo como base legal a Constituição. Ademais, segundo o redator, o Império teria "outras Sociedades de eleição popular", a exemplo das câmaras municipais e dos conselhos gerais, que com "mais peso" poderiam emitir representações ao Parlamento ${ }^{61}$. O Paulista taxou a Sociedade de entidade composta por "proletários e miseráveis", numa clara tentativa de apequenar a expressividade política de seus membros ${ }^{62}$. Já O Observador Constitucional saiu em defesa da Sociedade Federal e repreendeu a atitude do "Paulistinha", visto como um "difamador" das ideias federativas ${ }^{63}$. Ao que parece, o segundo secretário da Sociedade Federal, Jaime da Silva Teles, fora encarregado de montar uma comissão cujo objetivo seria elaborar um novo projeto de reforma constitucional a ser enviado à Câmara dos Deputados, diferente daquele aprovado em outubro de $1831^{64}$. O pretenso intervencionismo da Sociedade Federal no processo de reforma reforçava a situação em que o problema não era mais se a Carta de 1824 deveria ou não ser alterada, mas, sim, como fazer isso. Alguns exaltados pretendiam ir além do projeto Miranda Ribeiro que não havia indicado, como visto, a escolha dos presidentes e dos comandantes das armas por meio de eleição.

Em fins de 1831, contudo, a reforma deixara definitivamente de ser uma aspiração exclusiva dos exaltados para ser abraçada, ainda que fragmentariamente, pela ala liberal moderada. Autores como Paulo Pereira de Castro acreditam que tal reposicionamento pode ser entendido como um alinhamento circunstancial dos mantenedores da Regência com uma oposição que se avolumava gradualmente e que via na hesitação dos moderados para com a reforma um ponto de fraqueza. Mais tarde, o próprio Evaristo da Veiga afirmaria, rememorando o ano de 1831, que A Aurora Fluminense se declarara em favor da federação não por convicção de princípios, mas por que se deveria "aceitar francamente" aquilo que era amplamente pleiteado ${ }^{65}$. Isso porque, inicialmente, por mais que angariasse adeptos entre os moderados, a reforma constitucional via sistema federativo não era aceita por todos. Sobre a federação pairava certo estigma decorrente da sua vinculação à república, à Confederação do Equador

\footnotetext{
${ }^{60}$ WERNET, Augustin. Sociedades políticas (1831-32). São Paulo: Cultrix, 1978. p.113-116.

${ }^{61}$ Novo Farol Paulistano, n. 40, 21/12/1831.

${ }^{62}$ CONTIER, Arnaldo. Op. Cit. p. 90.

${ }^{63}$ Observador Constitucional, n. 203, 19/01/1832.

${ }^{64}$ WERNET, Augustin. Op. Cit. p. 120.

${ }^{65}$ CASTRO, Paulo Pereira de. A “experiência republicana”, 1831-1840. In: HOLANDA, Sérgio Buarque de (org.). História geral da civilização brasileira. São Paulo: Difusão Europeia do Livro, 1978. p. 315-352; Aurora Fluminense, n. 718, 07/01/1833.
} 
e à abordagem negativa feita sobre o tema por d. Pedro em sua segunda viagem a Minas Gerais ${ }^{66}$.

Ocorre que a reforma e o debate acerca do sistema federativo ganharam uma conotação positiva para os moderados que, em meio à instabilidade política da época, viram na ampliação dos poderes provinciais, sobretudo os de ordem legislativa e fiscal, uma forma de garantirem-se no poder e assegurar a continuidade do regime monárquico-constitucional representativo. Diante de tantas indefinições, parte dos moderados avaliou que era melhor "capitalizar os ganhos para si, evitando que seus oponentes radicais assumissem a dianteira dos acontecimentos"67. É possível que os moderados apostassem num arrefecimento do clamor reformista, o que resultaria em uma reforma mais pontual, sem alterações drásticas. Para os moderados, enfim, a federação havia se tornado um instrumento político que possibilitaria consubstanciar, ainda que provisoriamente, interesses distintos acerca da organização da máquina pública e, ainda assim, viabilizar a concepção de um Estado forte. Dessa forma, ao invés de acatar as mais variadas aspirações federalistas, os moderados buscaram dar o tom da mudança, visto que a "palavra federação" tinha "perdido o odioso que se lhe tinha apegado"68.

Caso emblemático dessa guinada pró-federação foi o advento de O Federalista, periódico paulistano redigido pelo acadêmico José Inácio Teixeira da Mota e que circulou entre fevereiro e julho de 1832. Apesar de seu nome remeter diretamente ao ideário republicano norte-americano, O Federalista foi um jornal moderado que se valeu do afã reformista para readequar o eixo das transformações, particularmente ao tópico da federação. De forma contundente, minimizou a acepção republicana do termo "federação", ressaltando suas possíveis vinculações com o sistema monárquico:

A escolha da denominação desta folha tem por fundamento a persuasão de que esta província deseja ardente e sinceramente as reformas no sentido federativo, bem como que elas sejam efetuadas unicamente pelos meios legais, isto é, por aqueles meios que marca [sic] a Constituição do Estado (...). Se pois é verdade que o princípio ou o sistema federativo é dominante no Brasil, resta-nos agora indagar se do desenvolvimento desse princípio como se crê geralmente, nasce a satisfação das necessidades das províncias... ${ }^{69}$.

Se a ressignificação da ideia de federação pelo discurso moderado nutria algo de circunstancial e atrelado à luta pelo poder, convém ficar claro que ela esteve associada, também, à conscientização por parte dos políticos de que a sujeição dos negócios provinciais ao Rio de Janeiro poderia culminar no efeito reverso do que se imaginava, ou seja, ao invés de reforçar a unidade do Estado, essa dependência faria da política provincial um foco de desagrado, quando não uma ferramenta de combate político dentro do Legislativo para outros fins. Tal percepção, portanto, não nasceu da noite para o dia e, sim, sucedeu do debate político e do conjunto de experiências adquiridas desde o tempo das juntas de governo, passando pelos conselhos provinciais e pelas relações que estes travaram com o Legislativo e Executivo.

\section{Considerações finais}

Se até meados de 1830 a imprensa de São Paulo notabilizou-se pela oposição movida ao governo de d. Pedro, ressaltando a necessidade de se respeitar o regime monárquico-constitucional diante dos abusos de poder do Ministério e do Conselho de Estado, depois disso o cenário tomou contornos mais complexos. Após a abdicação, sem representantes caramurus ou restauradores, a imprensa paulista foi palco de acirrado enfrentamento entre liberais exaltados e moderados, que teve como cerne de discussão o delineamento de um governo constitucional sem a presença do duque de Bragança.

Com a retirada de cena de $\mathrm{d}$. Pedro houve um aguçamento da interdependência das esferas provincial e nacional, mesmo porque elementos locais passaram a pressionar o governo do Rio de Janeiro por mudanças de agenda política e, sobretudo, por diligência dos exaltados, a clamar por alterações na Carta Magna. Se em São Paulo a imprensa moderada funcionou como ponto de apoio da Regência, prestando-se a legitimar ações do Executivo e da base governista no Legislativo, no Parlamento ficava cada dia mais nítida a necessidade de uma transfiguração no alicerce político do

\footnotetext{
${ }^{66}$ SILVA, Wlamir. Op. Cit. 2009, p. 200.

${ }^{67}$ BASILE, Marcello. O laboratório da nação... Op. Cit., p. 193.

${ }^{68}$ Novo Farol Paulistano, n. 56, 22/02/1832.

${ }^{69}$ Federalista, n. 1, 19/02/1832.
} 
Império que desse conta de garantir os interesse locais sem que eles colidissem uns com os outros, obstando os trabalhos do Legislativo e a governabilidade do Executivo, que saíra enfraquecido com a Lei da Regência.

Ao longo do texto foi possível questionar a suposta homogeneidade política de São Paulo, conjectura forjada pelos políticos moderados e que foi reiterada, posteriormente, por parcela da bibliografia que tematizou a história da província na primeira metade do século XIX. Confrontando os discursos de periódicos como O Farol Paulistano, O Observador Constitucional e A Voz Paulistana, observaram-se nuanças nas práticas liberais, especialmente no período entre 1830 e 1832, quando moderados e exaltados protagonizaram os principais enfrentamentos políticos na província. Longe de constituir um reduto da moderação, a província assistiu à defesa de projetos distintos de organização do Estado, de modo que vocábulos como "república", "federação", "monarquia federativa" e "monarquia constitucional" passaram a fazer parte do debate no período.

Hesitantes quanto à maneira como seria direcionada a reforma, mas também cientes de que a situação do Império era delicada, periódicos como O (Novo) Farol Paulistano martelavam a ideia de que as mudanças na constituição eram cobiçadas por toda a nação, daí ser praticamente irresistível. Que fosse almejada por vários setores era evidente, mas o que se escondia por trás dessa suposta inevitabilidade da reforma era o temor dos moderados de que as coisas saíssem do controle e exorbitassem a lei. Era melhor assenhorar-se da reforma, restringindo seu teor, do que deixá-la fluir em outras mãos, sobretudo dos exaltados. Tal procedimento sinalizava uma vitória parcial da concepção moderada de reforma, feita dentro da lei e sem a convocação de uma Constituinte.

O debate sobre a reforma constitucional se deflagrou no crescente espaço público da capital e das províncias, em meio à proliferação de associações políticas e periódicos de orientações políticas variadas, e que logo foi encampado pelo Legislativo. $\mathrm{O}$ que à primeira vista pode parecer uma relação de causa e efeito entre a necessidade de modificações na Carta de 1824 e os desdobramentos para sua implantação, a rigor foi um meticuloso processo de significação e ressignificação da pauta reformista. Do que se conclui que a reforma não constituiu mera questão institucional, mas antes o enfrentamento entre diferentes concepções de Estado e entre o que se entendia, a partir de experiências acumuladas nos últimos anos e dos exemplos vindos da Europa e dos Estados Unidos, a respeito do governo representativo. Em outro sentido, a querela reformista virou palco para que muitos dos promotores do 7 de abril justificassem seus atos como uma retomada da revolução encetada à época da Independência, cuja extensão em termos de configuração da cidadania e do Estado fora diminuída pelo fechamento da Constituinte em 1823.

A reforma constitucional, todavia, demoraria a se consolidar. Do início de 1832 até 1834 ocorreriam inúmeras reviravoltas que alterariam significativamente o quadro da política imperial e, por conseguinte, desfigurariam o projeto original de reforma. Assim como outras províncias, São Paulo assistiria a um racha interno dos moderados, que ficaria mais evidente após a conturbada aprovação do Ato Adicional.

\section{Referências bibliográficas}

\section{Fontes documentais}

BRASIL. Anais do Parlamento Brasileiro. Câmara dos Deputados (1826-1834). Rio de Janeiro: Tipografia de Hipólito José Pinho e Cia., 1874-79.

Hemeroteca Digital Brasileira

A AURORA FLUMINENSE (RJ)

ESTRELA MARIANENSE (MG)

MINAS GERAIS. Arquivo Público Mineiro.

O FAROL PAULISTANO (SP)

O FEDERALISTA (SP)

O MENTOR DAS BRASILEIRAS (MG) 
O NOVO FAROL PAULISTANO (SP)

O OBSERVADOR CONSTITUCIONAL

O PREGROEIRO CONSTITUCIONAL (MG)

O UNIVERSAL (MG)

SÃO PAULO. Arquivo do Estado de São Paulo.

SÃO PAULO. Arquivo do Estado de São Paulo. Ofício de 12/06/1833. Acervo Digital - Ofícios Diversos.

\section{Fontes secundárias}

BASILE, Marcello. O Império em construção: projetos de Brasil e ação política na Corte regencial. Tese (Doutorado em História), Universidade Federal do Rio de Janeiro, Rio de Janeiro, 2004.

O laboratório da nação: a era regencial (1831-1840). In: GRINBERG, Keila; SALLES, Ricardo (org.). O Brasil imperial. Rio de Janeiro: Civilização Brasileira, 2009. p. 53-120.

"O negócio mais melindroso": reforma constitucional e composições políticas no Parlamento regencial (1831-1834). In: NEVES, Lúcia Maria Bastos Pereira das (org.). Livros e impressos: retratos dos Setecentos e dos Oitocentos. Rio de Janeiro: Eduaerj, 2009. p. 185-209.

Projetos de Brasil e construção nacional na imprensa fluminense (1831-1835). In: FERREIRA, Tania Maria Bessone da C.; MOREL, Marco; NEVES, Lucia Maria Bastos Pereira (org.). História e imprensa: representações culturais e práticas de poder. Rio de Janeiro: DP\&A/ Faperj, 2006. p. 60-93.

BITTENCOURT, Vera Lúcia Nagib. De alteza real a imperador: o governo do príncipe d. Pedro, de abril de 1821 a outubro de 1822. Tese (Doutorado em História), Faculdade de Filosofia, Letras e Ciências Humanas, Universidade de São Paulo, São Paulo, 2007.

BOURDIEU, Pierre. O poder simbólico. Lisboa: Difel, 1989.

CARVALHO, José Murilo de (org.). Nação e cidadania no Império: novos horizontes. Rio de Janeiro: Civilização Brasileira, 2007.

CARVALHO, Marcio Eurélio Rios de. Afirmação de uma esfera pública de poder em Minas Gerais (1821-1851). Tese (Doutorado em História), Universidade Federal de Minas Gerais, 2003.

CASTRO, Paulo Pereira de. A “experiência republicana”, 1831-1840. In: HOLANDA, Sérgio Buarque de (org.). História geral da civilização brasileira. São Paulo: Difusão Europeia do Livro, 1978. p. 315-352.

CONTIER, Arnaldo. Imprensa e ideologia em São Paulo, 1822-1842: matizes do vocabulário político e social. Petrópolis: Vozes, 1979.

DOLHNIKOFF, Miriam. São Paulo na Independência. In: JANCSÓ, István (org.). Independência: história e historiografia. São Paulo: Hucitec/Fapesp, 2005. p. 557-575.

. O pacto imperial: origens do federalismo no Brasil. São Paulo: Globo, 2005.

FERREIRA, Tania Maria Bessonde da C.; MOREL, Marco; NEVES, Lucia Maria Bastos Pereira (org.). História e imprensa: representações culturais e práticas de poder. Rio de Janeiro: DP\&A/ Faperj, 2006.

FONSECA, Silvia Carla Pereira de Brito. Federalismo: a experiência americana de um conceito (1820-1835). Locus, vol. 36, n. 1, p. 85-116, 2013.

FREITAS, Afonso de. A imprensa periódica de São Paulo. Revista do Instituto Histórico e Geográfico de São Paulo, vol. 19, p. 322-1133, 1915.

GOUVÊA, Maria de Fátima Silva. O Império das províncias. Rio de Janeiro, 1822-1889. Rio de Janeiro: Civilização Brasileira/Faperj, 2008.

GRINBERG, Keila; SALLES, Ricardo (org.). O Brasil imperial. Rio de Janeiro: Civilização Brasileira, 2009.

HÖRNER, Erik. A tribuna em praça pública: debate político na imprensa periódica paulistana (1838-1842). In: OLIVEIRA, Cecilia L. de Salles; PRADO, Maria Lígia Coelho; JANOTTI, Maria de Lourdes Mônaco (org.). A história na política, a política na história. São Paulo: Alameda, 2006. p. 59-80.

KOSELLECK, Reinhart. "Espaço de experiência" e "horizonte de expectativa": duas categorias históricas. In: Idem. Futuro passado: contribuição à semântica dos tempos históricos. Tradução de Wilma Patrícia Maas e Carlos Almeida Pereira. Rio de Janeiro: Contraponto/PUC-Rio, 2006. p. 305-308.

LUNA, Francisco Vidal; KLEIN, Herbert S. Evolução da Sociedade e Economia Escravista de São Paulo, de 1750 a 1850. São Paulo: Edusp, 2006.

MARSON, Izabel Andrade; OLIVEIRA, Cecilia Helena de Salles. Liberalismo, monarquia e negócios: laços de origem. 
In: MARSON, Izabel Andrade; OLIVEIRA, Cecilia Helena de Salles (org.). Monarquia, liberalismo e negócios no Brasil: 1780-1860. São Paulo: Edusp, 2013. p. 9-33.

MARTINS, Ana Luiza; LUCA, Tania Regina de (org.). História da imprensa no Brasil. São Paulo: Editora Contexto, 2008.

MOREL, Marco. As transformações dos espaços públicos: imprensa, atores políticos e sociabilidade na cidade imperial (1820-1840). São Paulo: Hucitec, 2005.

. O período das regências (1831-1840). Rio de Janeiro: Jorge Zahar Editora, 2003.

NEVES, Lucia Maria Bastos Pereira das. São Paulo e a Independência. In: SILVA, Maria Beatriz Nizza da (org.). História de São Paulo colonial. São Paulo: Ed. Unesp, 2009. p. 275-318.

NOGUEIRA, J. L. de A. A Academia de São Paulo. Tradições e reminiscências. São Paulo: Saraiva, 1977.

OLIVEIRA, Carlos Eduardo França de. Poder local e palavra impressa: São Paulo, 1824-1834. São Paulo: Annablume/ Fapesp, 2011.

. Construtores do império, defensores da província: São Paulo e Minas Gerais na formação do estado nacional e dos poderes locais, 1823-1834, $1^{\text {a }}$ ed. Porto Alegre: PUCRS, 2017.

OLIVEIRA, Cecilia Helena L. de Salles. A astúcia liberal. Relações de mercado e projetos políticos no Rio de Janeiro (1820-1824). São Paulo: Ícone e Edusf, 1999. p. 80.

. São Paulo e a Independência. In: CAMARGO, Ana Maria de Almeida (org.). São Paulo, uma longa história. São Paulo: Centro de Integração Escola/Empresa, 2004. p. 39-58.

OLIVEIRA, Cecilia Helena L. de Salles; BITTENCOURT, Vera Lúcia N.; COSTA, Wilma Peres (org.). Soberania e conflito: configurações do estado nacional no Brasil do século XIX. São Paulo: Hucitec, 2010.

PEIXOTO, Antônio Carlos; GUIMARÃES, Lucia Maria Paschoal; PRADO, Maria Emília (org.). O liberalismo no Brasil imperial: origens, conceitos e prática. Rio de Janeiro: Editora Revan, 2001.

PETRONE, Maria Thereza Schorer. A lavoura canavieira em São Paulo. Expansão e declínio (1765-1851). São Paulo, Difusão Europeia do Livro, 1968.

. O barão de Iguape. Um empresário da época da Independência. São Paulo: Cia. Editora Nacional, 1976.

RIBEIRO, Gladys (org.). Brasileiros e cidadãos: modernidade política, 1822-1930. São Paulo: Alameda, 2009.

ROSANVALLON, Pierre. La monarchie impossible. Les Chartes de 1814 et de 1830. Paris: Fayard, 1994.

. Por uma história do político. São Paulo: Alameda Casa Editorial, 2010.

SILVA, Wlamir. "Liberais e povo": a construção da hegemonia liberal-moderada na província de Minas Gerais (1830-1834). São Paulo: Hucitec, 2009.

SLEMIAN, Andréa. Sob o império das leis: constituição e unidade nacional na formação do Brasil (1822-1834). Tese (Doutorado em História), Faculdade de Filosofia, Letras e Ciências Humanas, Universidade de São Paulo, 2006.

WERNET, Augustin. Sociedades políticas (1831-32). São Paulo: Cultrix, 1978. p.113-116.

VAMPRÉ, Spencer. Memórias para a história da Academia de São Paulo. São Paulo: Saraiva, 1925. 